Prepared for the U.S. Department of Energy under Contract DE-AC05-76RL01830

\title{
EM-21 Retrieval Knowledge Center: Waste Retrievall Challenges
}

AP Fellinger ${ }^{1}$

EJ Berglin ${ }^{2}$

MR Poirier ${ }^{1}$

BA Martin ${ }^{3}$

E Saldivar ${ }^{3}$

NF Chapman ${ }^{4}$

PW Gibbons ${ }^{5}$
MW Rinker ${ }^{2}$

$\mathrm{RL}_{\text {Minichan }}{ }^{1}$

PA Gauglitz ${ }^{2}$

BK Hatchell ${ }^{2}$

OD Mullen²

BE Wells ${ }^{2}$

April 2009

${ }^{1}$ Savannah River National Laboratory

${ }^{2}$ Pacific Northwest National Laboratory

${ }^{3}$ Savannah River Nuclear Solutions, LLC

${ }^{4}$ Washington Savannah River Company

${ }^{5} \mathrm{PW}$ Gibbons, Inc 


\title{
DISCLAIMER
}

This report was prepared as an account of work sponsored by an agency of the United States Government. Neither the United States Government nor any agency thereof, nor Battelle Memorial Institute, nor any of their employees, makes any warranty, express or implied, or assumes any legal liability or responsibility for the accuracy, completeness, or usefulness of any information, apparatus, product, or process disclosed, or represents that its use would not infringe privately owned rights. Reference herein to any specific commercial product, process, or service by trade name, trademark, manufacturer, or otherwise does not necessarily constitute or imply its endorsement, recommendation, or favoring by the United States Government or any agency thereof, or Battelle Memorial Institute. The views and opinions of authors expressed herein do not necessarily state or reflect those of the United States Government or any agency thereof.

\author{
PACIFIC NORTHWEST NATIONAL LABORATORY \\ operated by \\ BATTELLE \\ for the \\ UNITED STATES DEPARTMENT OF ENERGY \\ under Contract DE-AC05-76RL01830 \\ Printed in the United States of America \\ Available to DOE and DOE contractors from the \\ Office of Scientific and Technical Information, \\ P.O. Box 62, Oak Ridge, TN 37831-0062; \\ ph: (865) 576-8401 \\ fax: $(865) 576-5728$ \\ email: reports@adonis.osti.gov
}

\author{
Available to the public from the National Technical Information Service, \\ U.S. Department of Commerce, 5285 Port Royal Rd., Springfield, VA 22161 \\ ph: (800) 553-6847 \\ fax: (703) 605-6900 \\ email: orders@ntis.fedworld.gov \\ online ordering: http://www.ntis.gov/ordering.htm
}




\section{Executive Summary}

EM-21 is the Waste Processing Division of the Office of Engineering and Technology within the U.S. Department of Energy's (DOE) Office of Environmental Management (EM). In August 2008, EM-21 began an initiative to develop a Retrieval Knowledge Center (RKC) to provide DOE, its high level waste retrieval operators, and technology developers with a focused effort to share knowledge and expertise for addressing retrieval challenges across the DOE complex. The RKC is also designed to facilitate information sharing across the DOE waste site complex through workshops and through the development of a searchable database of waste retrieval technology information. The database may be used to research effective technology approaches for specific retrieval tasks and to take advantage of the lessons learned from previous operations. It is also expected to be effective for remaining current with the state of the art in retrieval technologies and with ongoing technology development within the DOE complex. To encourage collaboration between DOE sites in solving waste retrieval issues, the RKC team is co-led by Savannah River National Laboratory (SRNL) and Pacific Northwest National Laboratory (PNNL).

Two RKC workshops were held in Fall 2008. The purpose of these workshops was to define toplevel waste retrieval functional areas, exchange lessons learned, and develop a path forward to support a strategic business plan focused on technology needs for retrieval. The primary participants involved in these workshops included retrieval personnel and national laboratory staff associated with Hanford and the Savannah River Site, since the majority of remaining DOE waste tanks are located there. This report summarizes and documents the results of the initial RKC workshops. Technology challenges identified from these workshops and presented in this report are expected to set the direction for future RKCdirected tasks and facilitate tank waste retrieval solutions. 



\section{Acronyms and Abbreviations}

$\begin{array}{ll}\text { DOE } & \text { Department of Energy } \\ \text { DST } & \text { Double Shell Tank } \\ \text { EM } & \text { Environmental Management } \\ \text { HLW } & \text { High Level Waste } \\ \text { LLW } & \text { Low Level Waste } \\ \text { LFL } & \text { Lower Flammability Limit } \\ \text { OET } & \text { Office of Engineering and Technology (DOE) } \\ \text { PNNL } & \text { Pacific Northwest National Laboratory } \\ \text { PPE } & \text { Personal Protective Equipment } \\ \text { RKC } & \text { Retrieval Knowledge Center } \\ \text { SRNL } & \text { Savannah River National Laboratory } \\ \text { SRNS } & \text { Savannah River Nuclear Solutions } \\ \text { SRS } & \text { Savannah River Site } \\ \text { SST } & \text { Single Shell Tank } \\ \text { SSC } & \text { Structures, Systems and Components } \\ \text { TFA } & \text { Tanks Focus Area }\end{array}$





\section{Contents}

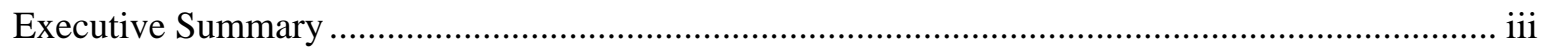

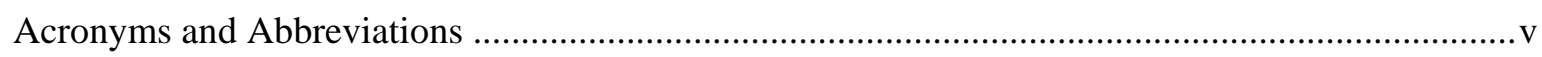

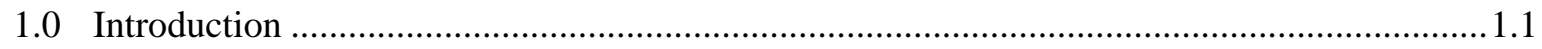

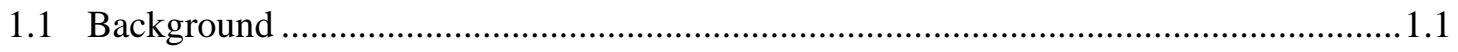

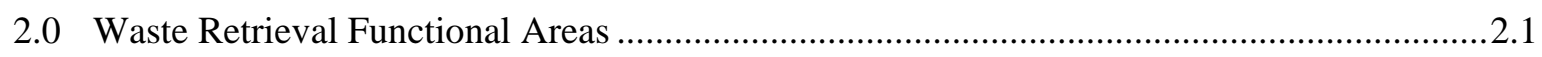

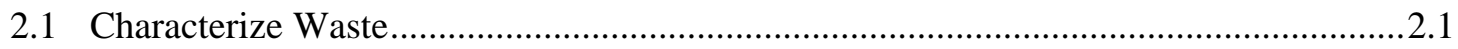

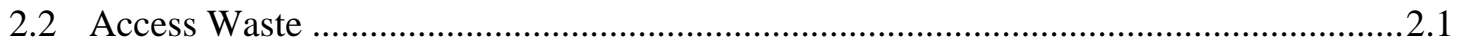

2.3 Dislodge / Mobilize Waste .......................................................................................2.2

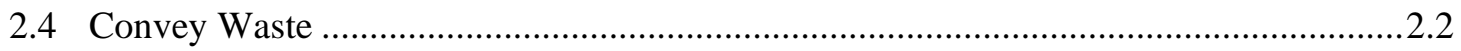

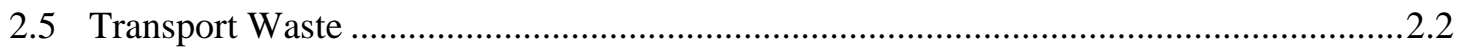

3.0 Waste Retrieval Challenges .......................................................................................... 3.1

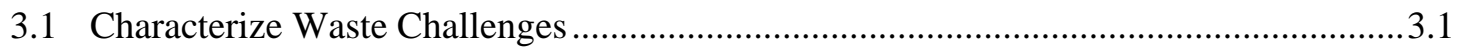

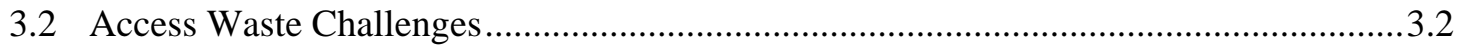

3.3 Dislodge/Mobilize Waste Challenges .............................................................................. 3.3

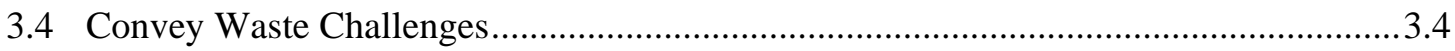

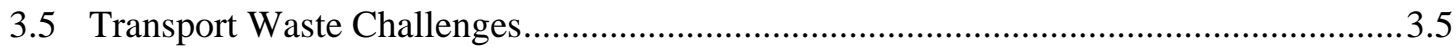

3.6 Other General Waste Retrieval Challenges................................................................. 3.5

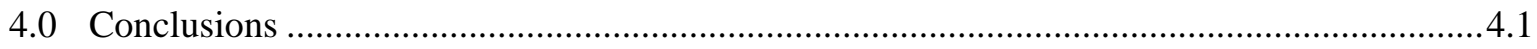

Appendix A EM-21 Tank Waste Retrieval Requirements Strategic Planning Session at HanfordA.1 Appendix B EM-21 Tank Waste Retrieval Requirements Strategic Planning Session at Savannah

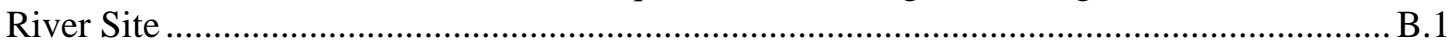

Appendix C EM-21 - “Retrieval Technology Program Needs and Recommendations” by Pete

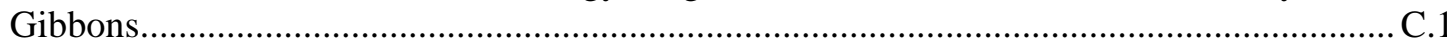

Appendix D PNNL / SRNL FY09 RKC Plan - January 2009 …................................................... D.1

\section{Figures}

2.1 Waste Retrieval Functional Areas 



\subsection{Introduction}

This document describes top-level waste retrieval functions and identifies areas of technical deficiencies related to future waste retrieval operations at U.S. Department of Energy (DOE) sites. Current and past waste retrieval work at DOE's Hanford and Savannah River Sites was assessed through two technical exchange workshops. This assessment also builds on past work performed by the Tanks Focus Area. The following appendices are provided as supplemental information related to previous workshops and retrieval activities:

- Hanford Site Workshop - September 11, 2008 (Appendix A)

- Savannah River Site Workshop - October 22, 2008 (Appendix B)

- White Paper - “Retrieval Technology Program Needs and Recommendations” by Pete Gibbons, former retrieval lead in the Tanks Focus Area program October 1, 2008 (Appendix C)

- Retrieval Knowledge Center FY09 Strategy and Operating Plan - January 2009 (Appendix D)

This information serves as the foundational basis for the Retrieval Knowledge Center (RKC) as defined in the background section below. Retrieval technology deficiencies identified in this document will be evaluated, prioritized, and then investigated as part of RKC's effort to facilitate DOE complexwide collaboration and waste retrieval solutions.

Five primary waste retrieval functions are discussed in this report: Characterize Waste, Access Waste, Dislodge/Mobilize Waste, Convey Waste and Transport Waste. The functions are defined within boundaries, i.e. scope, of one function beginning and another ending. For each function, the basis and gaps in technologies and processes are identified. Where applicable, crossover of functions or technical gaps into areas outside of retrieval, such as tank closure, are highlighted. The term "tank" as used in this document refers to a vessel holding waste. History dictates that no two high level waste (HLW) tanks are the same in every aspect, and therefore the functions and resulting resolutions to retrieval challenges must ultimately be tailored to the specific conditions of each tank.

\subsection{Background}

The DOE's Office of Environmental Management (EM) is responsible for risk reduction and cleanup of the environmental legacy of the nation's nuclear weapons program. EM-21 is the Waste Processing division of the Office of Engineering and Technology within DOE-EM. The EM-21 technology program has several key technical areas, including improved waste storage, reliable and efficient waste retrieval, enhanced tank closure processes, next generation pretreatment solutions, enhanced stabilization, challenging materials, and spent nuclear fuels.

In August 2008, EM-21 began an initiative to develop a Retrieval Knowledge Center (RKC) to provide DOE, its high level waste retrieval operators, and technology developers with a centralized and focused location to share knowledge and expertise to address retrieval challenges across the DOE complex. The RKC is also designed to facilitate information sharing across the DOE waste site complex through workshops and through a searchable database of waste retrieval technology information. The RKC team will assess available information to identify waste retrieval challenges and technical gaps that could benefit from technology advancement. Ongoing RKC activities will focus on solutions for the most 
important challenges identified in the initial RKC work. Hanford and the Savannah River Site have most of the DOE waste tanks, and so the majority of the retrieval challenges to be addressed are expected to originate there. However, other DOE sites with waste storage tanks are likely to capitalize on this information. Additional information on the RKC can be found in the current "Retrieval Knowledge Center FY2009 Strategy and Operating Plan,” initially released in January 2009 (see Appendix D). 


\subsection{Waste Retrieval Functional Areas}

Waste retrieval has been broken down into five functional areas: characterize waste, access waste, dislodge/mobilize waste, convey waste, and transport waste, as shown in Figure 2.1, Waste Retrieval Functional Areas.

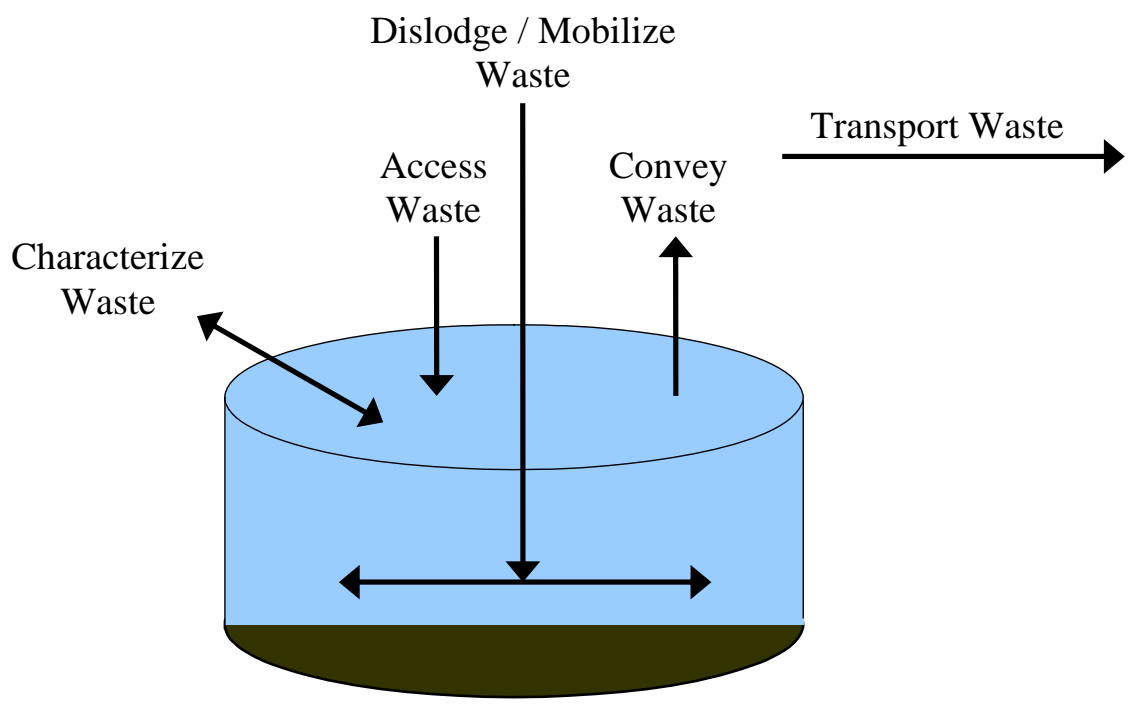

Figure 2.1. Waste Retrieval Functional Areas

A brief definition and scope for each of the retrieval functional areas is given below. More detailed information about each of these functional areas, including their definition, basis, limitations, and history, can be found in Appendix $\mathrm{C}$ under the associated function heading.

\subsection{Characterize Waste}

The Characterize Waste functional area consists of the processes and tools necessary to understand the waste properties of a particular tank and may include waste forms (solids, liquids, and gases inventories), waste property type (physical, chemical and radiological), and waste conditions (mobilized and in-situ). This function may be performed through specific sampling or in-situ methods prior to and during retrieval operations. Although the scope for characterization of waste for retrieval purposes may not specifically include the characterization necessary for tank closure, the same technologies, tools, and methods used for retrieval characterization may be expected to apply.

\subsection{Access Waste}

The Access Waste functional area is the breaching of the physical tank boundary to access the interior of the tank for the deployment of waste retrieval equipment. Tank access locations for waste retrieval may be existing penetrations or new ones installed specifically for retrieval operations. 


\subsection{Dislodge / Mobilize Waste}

Dislodge/Mobilize Waste functional area is the process of transforming the tank waste, allowing it to be removed from the tank by the waste conveyance system. Waste dislodging breaks up applicable portions of the waste either mechanically or chemically from the mass-typically solids, salts, heavy sludges, or similar - so they can be mobilized. Waste mobilization moves the waste to the conveyance system and alters the waste form as applicable to allow removal of the waste by the conveyance system.

\subsection{Convey Waste}

Convey Waste functional area is the action of moving dislodged and mobilized waste out of the waste tank, through the access tank boundary, to a location where the transport waste function can move it to its new destination; typically a storage or staging tank. The convey function includes any manipulations, such as water addition, trim chemicals, grinding, etc., that are needed to move the waste to the interface point—typically the top of the underground tank—with the Transport Waste Function.

\subsection{Transport Waste}

Transport Waste functional area is the equipment and processes necessary to move retrieved waste from the original location, or sending tank, to another location, the receipt tank, typically by pumping waste through underground transfer piping. The boundary of the transport function starts at the interface with the conveyance function and ends with the interface at the destination location, typically a waste holding tank. The ability to freely move waste should avoid pipe plugging and compatibility with any waste/tank conditions at the destination location are key Transport Waste functions. 


\subsection{Waste Retrieval Challenges}

The charter of the RKC is to facilitate to the advancement of waste tank retrieval across the DOE sites. Identification of the challenges related to tank waste retrieval is an important element of the overall RKC strategy. This section summarizes the key waste retrieval challenges resulting from recent Hanford and Savannah River Site workshops with tank waste retrieval personnel and review of past documentation.

Waste retrieval challenges are both technical and non-technical. The challenges presented below are primarily technical challenges because they create the foundation needed to execute the RKC strategy. These technically-oriented challenges can be addressed directly, and are not as easily impacted by redirection in policy. While important to the overall success of retrieval and tank closure activities, the RKC has little ability to influence change to non-technical challenges. Non-technical challenges such as funding, management support, and regulatory decisions, will be addressed at a high level as it pertains to each of the Waste Retrieval function areas.

Previous major documented assessments of waste tank retrieval challenges include DOE's Tank Focus Area program, disbanded in 2002. Many of the challenges that exist today are similar to those previously assessed, although, this new evaluation of waste tank retrieval challenges is made in light of passing time, lessons learned, new personnel, regulatory changes, technological advancement, and other factors that give new focus for advancing waste tank retrieval efforts.

The tank waste retrieval challenges described below are categorized by applicable waste retrieval functions. These challenges should not be weighted or prioritized, because the RKC will take this task as the waste retrieval progresses.

\subsection{Characterize Waste Challenges}

Previous attempts to analyze waste in support of retrieval operations through various methods including core sampling, grab sampling, or smear sampling, have not yielded desired results in a timely fashion.

Key challenges to characterize waste function include:

a. Equipment For Waste Characterization

Past sampling activities have required pulling samples and removing from the waste tank to obtain waste characterization data to determine methods for retrieval and transfer, as well as, the in-progress state of cleaning. Waste retrieval sampling is generally costly, risky, and can be lengthy (sample tool development to reported analysis). In-situ tools and equipment that could perform sampling characterization activities remotely, in real time are highly desirable because they lend themselves to quicker turnaround of results and an ability to allow the characterization to direct early decision points for retrieval. There is also a challenge to having a suite of tools that reach and access difficult to locate areas of the tank or system whether for in-situ or laboratory analysis. It is also notable that this function is challenged by no firm basis for what is needed to support closure planning_cleaning effectiveness, diminishing returns, etc.

b. Slow Turnaround Of Sample Analyses

Currently, analyses are performed thorough characterization of samples supporting process flow 
sheet development; ultimately sustaining additional processing of retrieved waste. As the need for rapid removal of waste emerges, faster turnaround of laboratory analyses needed for processing will be challenged by limited resources and lengthy analytical durations. Challenges exist in methods, equipment and expertise needed for waste tank characterization that ultimately impact retrieval and closure campaigns.

c. Inadequate Detection Limits For Species Of Interest

Oftentimes the concentration of species needs to be measured at a much lower level than the capability of the instruments available at the time of measurement. In some cases, the insufficient detection limit is due to the limits of the equipment. At other times, it is due to the high radiological dose of the sample, which requires dilution prior to analysis. Characterization tools need to be developed to achieve lower detection limits for these species of interest.

\section{d. Cross-Contamination Of Samples}

Samples are prepared remotely in shielded cells prior to analysis, and the cells may either be contaminated from decades of operation, or risk cross-contamination during preparation. This problem becomes significantly more evident when the concentration of species of interest is near detection limits. This should be evident for lower concentrations expected following retrieval and cleaning to support closure.

\subsection{Access Waste Challenges}

With the exception of normal transfer operations that use existing underground infrastructure, all waste retrieval methods require physical penetration of the tank. The waste to be retrieved is typically stored in 75 to 85 -foot diameter underground tanks. The top of these tanks are up to nine feet below grade to provide shielding. Underground piping is used for transfers to and from the tanks. From ground level, access to the tank is typically through risers built into the tank during initial construction. It has been shown that the installation of new, larger penetrations and access risers are possible. A typical tank can contain up to eight existing risers, 24 inches in diameter. Smaller risers are more numerous, but the 6 to 8 inch diameter holes are typically employed as inspection ports that can be used for instrument or camera access.

Key access waste challenges include:

a. Installing New Access Locations

Many tank access locations, typically tank risers, are not optimal for efficient retrieval operations due to the location and size. Use of existing access points often limits the type and placement of retrieval deployment systems that can be used. An approved and consistent process for installing new tank penetrations utilized by all of the HLW tank sites should be evaluated for deployment systems and equipment when existing penetrations are not available. While installing new penetrations and risers in a waste tank has been successfully demonstrated recently at the Savannah River Site and in the past at Hanford, the relatively high cost to install new risers, coupled with the risks (radiation exposure, structural integrity), make using this technology practice routinely a challenge.

\section{b. Cleaning Waste Tank Components (Ancillary Systems)}

There are clear technical challenges to accessing waste for retrieval in ancillary systems. Some tanks have documented leaks at certain levels within the tank - typically located at a weld joint. Many tanks have secondary containment, referred to as the tank annulus, that may have accumulated waste from leakage of the primary containment structure. Other tank components 
may have waste from leakage, such as internal tank cooling coils, and may also need to have waste retrieved to meet closure requirements.

\section{c. Remote Equipment To Limit Personnel Exposures}

Personnel radiation exposure and release of radioactive material are key risks to any operations that breach the primary and ancillary tank structure. Temporary containment in the form of a hut must be provided when a riser plug is removed. Personnel working in the proximity to an open tank must be protected with the appropriate Personal Protective Equipment (PPE). The radiation fields directly over an opening in the tank can be very high and should be avoided by personnel. The conditions around this work dictate careful planning and the use of engineered equipment to minimize personnel exposure. Remote equipment such as cameras, samplers, manipulators, or pumps are the desired resolution to several of the exposure issues. Alternatives such as these can be valuable options for decision makers. However, one-time specialized equipment can be costly and may be an afterthought of general planning efforts, making this area a particular challenge.

d. Equipment to Access Large Tank Areas and Work around Internal Obstacles

Tank depths can be expected to be approximately 24 to 34 feet, depending on the design and type of the tank. The distance to the waste will vary, depending upon the level of waste. Remote devices for viewing or performing retrieval tasks inside a tank may need to be over 40 feet long. To further complicate access, tanks are not large, open areas but typically, constricted by small riser access openings. Obstacles inside the tank such as structural supports, cooling coils, instruments, steam jets, or pumps, make remote navigation inside the tanks a particular challenge.

\section{e. Equipment To Contain/Ventilate Tank Gases}

The vapor space above the waste in these tanks is ventilated to prevent the accumulation of undesirable gases, typically hydrogen. Activities that manipulate the waste must consider the effect on hydrogen generation and the ventilation system capacity to keep the hydrogen levels below the Lower Flammability Limit (LFL).

\section{f. Equipment That Maintains The Structural Integrity Of The Waste Tank}

Preferred methods of accessing and deploying tank retrieval equipment can challenge the structural integrity of the tank. Retrieval usually requires heavy and substantial support structures (huts, compressors, cranes, scaffolding, portable control rooms, etc.) where tank riser or tank top loading is not allowed or desirable. In some cases, equipment design may not impart any load to the tank if the supporting structure completely bridges the tank and the structure is supported outside of the tank footprint.

\section{g. Robust Equipment That Can Be Removed From Tank When Work Completes}

Using existing physical resources in and around a tank when planning waste retrieval activities can present challenges, but also an opportunity to identify retrieval activities that can capitalize on the existing structures where possible. There is, therefore, an opportunity for activities to be much more cost-effective whenever existing structures, systems and components (SSCs), along with existing procedures, can be incorporated into retrieval plans. Existing tank top SSCs could also be a hindrance if they are positioned to block access to a particular riser. Devices developed for use inside the tank must incorporate structural integrity, so they are able to be removed when the task is complete. When items are left inside the tank, tank closure justification becomes more difficult.

\subsection{Dislodge/Mobilize Waste Challenges}

There are a number of criteria to be considered in developing strategies for the waste retrieval function to dislodge/mobilize waste as discussed in Appendix C. 
Key dislodge/mobilize waste challenges include:

a. Minimization of Secondary Waste Streams

Minimization of secondary waste streams that could result from dislodging and mobilizing waste during retrieval is a challenge. Almost all potentially viable chemical and mechanical techniques will generate additional waste in the forms of liquid or contaminated equipment. Down stream liquid volumes can be reduced through evaporation, although minimizing secondary waste streams reduces the demand on evaporators. Given that there is very little available space for additional liquid waste streams, minimizing liquid generated during retrieval is a primary challenge. Disposition of solid waste (pumps, crawlers, tools, etc.) generated during retrieval, and within the other tank closure areas such as ancillary system closure, is also generally regarded as undesirable because of added costs associated with decontamination, transportation, potential for exposure, or burial.

b. Matching The Dislodge/Mobilize Output With The Waste Conveyance System Strategies, systems, and processes designed to dislodge and mobilize the waste are often specialized to address a particular type of waste and/or waste in a particular location in the tank. Regardless of the method used to successfully dislodge/mobilize wastes during retrieval, it must be coupled with the ability to present the resulting material to the waste conveyance and subsequent waste transfer systems.

c. Compatibility Of Dislodged/Mobilized Waste With Existing Waste In Receiver Tank Finally, regardless of techniques to dislodge and mobilize waste and transport it from the tank, the impacts of those techniques should be clear. This presents a particular challenge to retrieval where early characterization of waste may have determined chemical and physical compatibility with the down stream process, but the effects of subsequently selected techniques to mobilize and transport the retrieved waste have high potential to alter those physical characteristics. Any material or chemical used during the waste retrieval process, such as chemical additions to dissolve a waste form, likely will change the chemistry of the waste form and should be evaluated for compatibility with the receiver tank and proposed down stream processes.

\section{d. Robust Equipment To Survive Harsh In-Tank Environment}

The tank waste environment is harsh - consisting of high radiation, abusive environment, and a large variety of waste chemicals and physical properties. In addition, many other obstacles exist including uneven surfaces, discarded equipment, and in-tank ancillary components and systems, resulting in complex operating conditions. Robust equipment is required to survive in this environment as equipment maintenance is costly, typically through a containment hut or glove bag enclosure, can significantly increase the safety risks and reduce the likelihood of success.

\subsection{Convey Waste Challenges}

The challenges to Convey Waste will typically occur during heel removal and overlap with the third function, dislodge/mobilize waste.

Key Convey Waste challenges are as follows:

a. Locating Equipment To Reach In-Tank Conveyance Location(s)

The ability to locate, or relocate as necessary, the in-tank conveyance point (i.e. inlet suction) to the mobilized waste is often necessary to effectively move the waste. This may be complicated by distance from the point of insertion and internal obstacles. 
b. Robust Equipment To Survive Harsh In-Tank Environment With Limited Maintenance This is the same challenge described in the dislodge/mobilize waste function section (see section $3.3 \mathrm{~d}$ ).

c. Determining Remaining Waste Volume In Tank For Retrieval Completion

Estimating and monitoring the residual tank waste during conveyance is necessary to determine when the retrieval is complete. Similar to challenges described in characterization for retrieval, this determination and monitoring of retrieval completion is complicated by residuals of the process (mists, vapors, sluicing, etc.).

d. Variance In Tank Waste Solid Loading From Dislodge/Mobilize Waste Function Conveyance challenges also exist in systems where solid loading is inconsistent, or spans a large range of sizes. If the solid loading is low, the retrieval process efficiency becomes a challenge. Conversely, if the solid loading is too high, plugging of the conveyance line is possible. Mechanical conveyance systems are often plagued by limited suction velocities, which tend to leave heavier solids behind.

e. Quantifying Waste Properties Being Conveyed

Accurately quantifying the mass of retrieved waste solids and liquid is difficult with existing instruments, which presents another challenge for the conveyance function. Monitoring of conveyed waste mass, volume, and material balance (i.e., properties) is needed to effectively monitor conveyed waste to support campaign completion and compatibility with receiver destinations (rates, volumes, etc.)

\subsection{Transport Waste Challenges}

\section{a. Unplugging Of Waste Transfer Lines}

Transfer of waste picked up from the conveyance system typically requires movement of the waste material for a significant distance through various transfer lines, pumps, transfer points, etc. Waste is typically transported between tanks and processes in a slurry form. In many cases, the slurries are non-Newtonian which complicates many transfer system designs. Maintaining the appropriate conditions to prevent settling and/or plugging in the waste lines presents a challenge. Parameters, such as percent solids in the slurry, transport velocity and flushing are critical values to prevent a plug in transport lines. In many cases, operating experience and procedures dictate these critical parameters; however, despite efforts to prevent plugging, transfer lines or equipment can still become blocked through solids buildup. Therefore, recovery methods must be developed and put in place to deal with a plug, allowing new retrieval operations to use those transfer lines.

\section{b. Waste Compatibility During/At Transport Destination (Handoff/Interface)}

The transported waste must be compatible with any waste at the transport destination, typically a waste tank, as well as the transport and destination equipment. An overall system plan that supports the disposition of retrieved waste is highly desirable for the successful hand-off of the waste for further processing. This hand-off is challenged technically by mechanical equipment constraints, unknown waste slurry properties, undeveloped processes and aged measurement technologies, and is further hindered by limited budgets, differing contracts, and varying priorities.

\subsection{Other General Waste Retrieval Challenges}

Four particular areas were noted during workshop discussions as having the most significant impact on future tank waste retrieval efforts (Appendices A and B). Focusing on these four lessons learned items, proven effective, will also facilitate positive impacts from the other eight items. 
The four areas that will have the most significant impact on future tank waste retrieval are as follows:

\section{a. Management Support And Priority}

A facility always has conflicting priorities and emerging crises that can divert the plans and attention of personnel working on long term activities. When a retrieval activity has management support and the necessary priority, the chance for success is dramatically increased. In most cases, the task will be completed more quickly and be less expensive with the appropriate management support.

\section{b. Cold Testing Of Equipment And Processes}

Remote equipment developed for retrieval tasks is typically one of a kind and specific to an identified task. Although, previous experience of the engineering staff provides a significant advantage, there is no substitute for practical operations in a mockup setting. Thorough testing and characterization of specialized devices and equipment in a clean environment provides an opportunity to resolve problems with the equipment before deployment and significantly improves the ability to recover in the field, ultimately resulting in the greatest probability of success. In the case of sampling and mechanical retrieval equipment this exercise is even further enhanced when a simulant of the material can be developed for use in testing.

c. Laboratory Support

Operating facilities must focus on day-to-day operations and often find it difficult to focus on long term issues or technological advancement. Laboratory support can provide the necessary scientific and engineering resources required to overcome waste retrieval challenges that exist at the DOE tank farm facilities. Collaboration between DOE laboratories, which focuses on common waste retrieval challenges, has the potential for even greater achievement.

\section{d. Formation Of Project Teams}

Project teams are very effective at solving complex problems such as waste retrieval. When a project team is developed an objective is identified and personnel are assigned to focus on a particular problem which signifies the task as a management priority. This is even more effective when the personnel are assigned full time to the effort without other distractions. Complex problems typically require a wide range of skills to resolve. A well designed project team, with the right cross-section of personnel, such as a project owner, facility personnel, engineering, scientists, and operators, provide a setting to achieve success. 


\subsection{Conclusions}

Waste tank retrieval experts from the Hanford and Savannah River Sites have categorized waste retrieval into five primary functions and outlined key technical challenges in this report.

Recommendations to accelerate and more efficiently retrieve waste from DOE tanks based on past experiences are given in Appendix C but key highlights proposed to moved retrieval technologies forward include the following:

- Consolidation of Retrieval Documentation - Update and reorganize previous tanks focus area (TFA) and newer information to include developments since 2002 to provide a single source tool to evaluate and communicate waste retrieval evolutions and applicability.

- Incremental Development of Retrieval Technologies - Develop and deploy waste retrieval technologies commensurate with the need, simple and inexpensive; progressing to more capable (and costly) technologies as needed based on the application.

- Perform Cold Mock-Up Of Retrieval Technologies - Develop a strategy that allows collection of relevant data with a minimal impact of site operations (through field observation and mock-up of equipment performance under controlled conditions).

- Define Technology Gaps - Define specific technology gaps and strategies to place new tools in waste retrieval tool box that will cover the spectrum of waste forms (soft, hard, soluble, etc.) and tank conditions (internal obstructions, small access ports, leaking tanks, etc.).

- Remove Barriers To Technology - Provide a communication mechanism to resolve technological (and programmatic) barriers to waste retrieval technologies.

- Waste Retrieval Workshops - Perform waste retrieval technology workshops and exchanges between DOE sites, retrieval function interfaces, and commercial vendors.

Although waste retrieval continues to present technical and programmatic challenges to the DOE, indentifying and addressing these challenges in an open forum as being developed by the RKC is expected to accelerate the DOE waste tank retrieval and subsequent tank closure activities. 



\section{Appendix A}

\section{EM-21 Tank Waste Retrieval Requirements}

Strategic Planning Session at Hanford 



\title{
EM-21 Tank Waste Retrieval Requirements Strategic Planning Session
}

September 11, 2008

\author{
Requested by: Mike Rinker, Tank Waste Program Manager \\ Pacific Northwest National Laboratory \\ Richland, WA
}

Facilitated by: Richard Harrington, CVS

Robin Kummer, CVS

Washington Closure Hanford

Richland, Washington 


\section{TABLE OF CONTENTS}

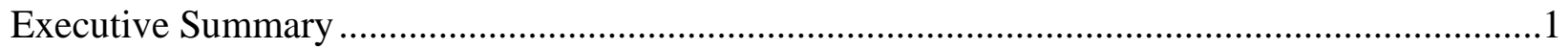

Appendices

A. Tank Waste Retrieval Technical Requirements and Challenges ........................................2

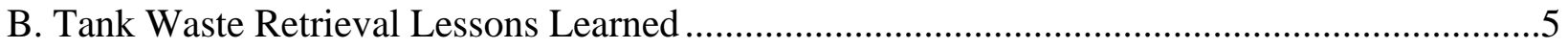

C. Agenda, Opening Remarks and Attendance Roster ...........................................................9 
EM-21 is the Waste Processing division of the Office of Engineering and Technology (OET), within the U.S. Department of Energy's (DOE's) Office of Environmental Management (EM). In August of 2008, EM-21 began a Retrieval and Closure initiative to develop a Retrieval Knowledge Center Strategy and work plan. Part of this effort focuses on a tank waste retrieval scope lead by Mike Rinker of Pacific Northwest National Laboratory (PNNL). In support of this effort Mr. Rinker requested a facilitated workshop to define top-level retrieval requirements and challenges, lessons learned, and path forward to support the EM-21 strategic business plan and future work.

The workshop was conducted on September 11, 2008, in the PNNL Environmental Technology Building (ETB), Wenatchee River Room. The multidisciplinary team included engineering and scientific representatives from PNNL, Savannah River National Laboratory (SRNL), and CH2M HILL. Appendix C contains the workshop session agenda, opening remarks, and attendance roster.

\section{Session Results}

The session was successful in the teams' development of current tank waste retrieval top-level requirements and challenges (Appendix A), waste retrieval lessons learned (Appendix B), and a path forward directed at utilizing these results to upgrade and finalize an fiscal year-end submittal in support of the EM-21 Retrieval Knowledge Center Strategy and Work Plan.

The top-level requirements and lessons learned were based off current Hanford and Savannah River site operations mission experience and future needs, by leveraging waste retrieval operations and Tank Focus Area (TFA) experience and completed work.

\section{Session Process}

The facilitator opened the session purpose, agenda, safety topic, team member introductions, and review of a high-level retrieval function diagram to focus the process. Mike Rinker delivered opening remarks that centered on thanking the team members for their support to fulfill the EM-21 strategy and vision for a technical database with top-level tank waste retrieval requirements, technical gaps, and lessons to facilitate DOE, tank farm operators, and technology solutions.

The top-level requirements were defined from the teams' collective input in five retrieval functional areas. Afterwards, all the requirements reviewed by the team to define the top current technical challenges (i.e. technical gaps). The lessons learned were developed from the team's response to two questions: What has worked well and what could have been done better. The lessons learned focus was to leverage TFA work, operations experience and future needs. The team prioritized each set of lessons based on their positive impact for successfully fulfill the waste retrieval missions.

The session concluded with a round robin close-out where each member was engaged for any last minute items and meeting utility. In summary, the team felt the workshop was value-added.

\section{Facilitator Comments}

The team did an excellent job of staying focused on the session purpose and covering a lot of ground in a short one-day effort. Moreover, the multidisciplinary team consisted of senior-level professionals who represented actual tank waste retrieval experience to-date and leveraged TFA work and lessons learned. Special thanks to Mike Rinker for his leadership in bringing together this multidisciplinary team of professionals who openly and actively exchanged past experience and defined the requirements and challenges to overcome for successful future waste retrievals. 


\author{
APPENDIX A \\ TANK WASTE RETRIEVAL \\ HIGH-LEVEL TECHNICAL REQUIREMENTS \\ AND \\ TECHNICAL CHALLENGES
}

Five Functional Areas:

Characterize Waste, Access Tanks, Dislodge/Mobilize Waste, Convey Waste and Transport Waste

\title{
1. CHARACTERIZE WASTE
}

- Total inventory

- Solids, liquids, and gas

* Solid properties

- Radiological properties

- Chemical properties

- Particle Size

- Density

- Solubility

- Rheaological

- Chemical properties for compatibility

- Understand retrieval method

* Measure the large/dense particles

* In-situ conditions (e.g., yellow bus/piano)

* = Technical challenge and/or gap 


\section{ACCESS TANKS}

- A hole (big)

- Riser size and location

* A new hole (cost effective)

- Tank integrity (e.g., structural)

- Maintain containment

- Maintain confinement

- Removal of hardware obstructions to existing holes

- Safety (people and environment)

- Cost and schedule impacts

- Approved process/procedure(s)

\section{DISLODGE/MOBILIZE WASTE}

* Compatibility with conveyance

- Protect the tank

- Define allowable media

* Minimize water usage

- Leak detection (e.g., LDMM)

- Reduce viscosity

- Flammable gas safety

* Get down to 360 cubic feet or less

- Ventilation

- Monitor mobilization progress

- Deployment

- Suite of tools

- Render waste conveyable

- Monitor tool and process conditions

* Negotiate internal obstructions

- Compatible within tank debris/waste

- Removable, maintainable, disposable and/or repairable

* Must be able to go to the waste

- Measurable criteria that defines when you are good enough to convey and/or done

- Retrieval rate

* = Technical challenge and/or gap 


\section{CONVEY WASTE}

* Capture/access waste (i.e., big and/or dense particles)

- Leave incompatible waste behind

- Conveyance method

- Conveyance destination

- Conveyance rate

- Compatible with balance of system(s) (up and down stream)

- Define continuous or batch

- Define lift

* Modify waste properties (acceptable to entire process)

NOTE: Was done on 2 out of 3 Hanford tanks

- Measure when done

- $\quad<360$ cubic feet

- Limits of technology

- Measure and/or confirm meets regulatory requirements (e.g., residual TRU)

* Monitor conveyed waste mass, volume, and material balance (i.e., properties)

- X-tank leak detection

- Minimize volume

- Monitor in comparison to waste feed delivery requirements

\section{TRANSPORT WASTE (From DST and/or Type III Tanks)}

* Meet receiver requirements (e.g., ICD-19) and required retrieval rate

- Leak detection

- Buffer capacities (i.e., excess rate)

* Prevent/mitigate plugging (velocity, temperature, solids loading, etc.)

- Waste form compatibility

- Monitor progress

- Quantify transfer volumes/mass

- Confinement/containment

- Adequate system (i.e., pressure, corrosion, design/layout, etc.)

- Compatible with very slow retrieval rates

- Radiation shielding

- Monitor receipt vessel

- Compatible with conveyance and receiving process

* Ensure batch homogeneity of feed to the facility

- Transport non-homogeneous waste

* Condition waste

- Minimize out-of-spec waste

* Sample and characterize (e.g., RDQO)

* = Technical challenge and/or gap 


\section{APPENDIX B}

\section{TFA AND TANK WASTE RETRIEVAL LESSONS LEARNED}

\section{What Worked Well and What Could Have Been Done Better}

\begin{tabular}{|c|c|}
\hline \multicolumn{2}{|r|}{ WHAT WORKED WELL } \\
\hline Item & \\
\hline 1 & $\begin{array}{l}\text { - Actions trumps analysis } \\
\text { - Sooner you use it the better }\end{array}$ \\
\hline $1 \mathrm{~A}$ & $\begin{array}{l}\text { - Integration of development and full-scale deployment, e.g., CH2M Hill used } \\
\text { full scale test facility and C-106 full scale test }\end{array}$ \\
\hline $1 \mathrm{~B}$ & $\begin{array}{l}\text { - Adequate scale testing and mock-up evaluation } \\
\text { - K-Basin long length contaminated equipment mock-up }\end{array}$ \\
\hline 2 & $\begin{array}{l}\text { - SMPs (Submersible Mixer Pumps) } \\
\text { • Used in tandem to get the heel }\end{array}$ \\
\hline 3 & $\begin{array}{l}\text { - Management ownership, e.g., management saying I own these tanks } \\
\text { (Cavanaugh Mimms) }\end{array}$ \\
\hline 4 & $\begin{array}{l}\text { - SY-101 remediation and mitigation } \\
\text { - Hits the mark of 1, 2, and } 3 \text { above for actual work } \\
\text { - Hose-in-hose transfer } \\
\text { - Integrated team }\end{array}$ \\
\hline 5 & $\begin{array}{l}\text { Early Regulator involvement in the process; e.g., supplemental technology } \\
\text { down select (bulk vit, steam reforming, and cast stone) }\end{array}$ \\
\hline 6 & $\begin{array}{l}\text { - Enough targeted mobilization energy such as bore-hole miner } \\
\text { • Over-design the tool as a risk mitigator }\end{array}$ \\
\hline 7 & $\begin{array}{l}\text { - } \text { End user, industry, and national laboratory teams, e.g., HTI } \\
\text { - Evaluated technology through demonstration the arm, crawlers, and sluicers } \\
\text { in a short period of time; i.e., several months vs. years }\end{array}$ \\
\hline 8 & $\begin{array}{ll}\text { - } & \text { Virtual prototyping } \\
\text { • } \quad \text { Modeling and simulation; e.g., robot technology }\end{array}$ \\
\hline 9 & - Keeping equipment out of the waste, e.g., ORNL GAAT \\
\hline
\end{tabular}

= Most significant impact on the future retrievals and the balance will follow 


\begin{tabular}{|c|c|c|}
\hline \multicolumn{3}{|r|}{ WHAT COULD HAVE BEEN “DONE BETTER” } \\
\hline Item & $\begin{array}{l}\text { New } \\
\text { Rank }\end{array}$ & \\
\hline 1 & & $\begin{array}{ll}\text { - } & \text { Uniform sampling } \\
\text { - } & \text { Representative, not just for convenience; e.g., SRS pump in a riser }\end{array}$ \\
\hline 2 & & $\begin{array}{l}\text { - Finish the job! e.g., INL: stopped prematurely on a waste processing step } \\
\text { and K Basins }\end{array}$ \\
\hline 3 & & - Collecting more in-process data; e.g., Hanford retrievals \\
\hline 4 & 1 & $\begin{array}{l}\text { - Application of available knowledge base; e.g., use of Hanford proven } \\
\text { processes at WTP; waste mobilization, transfer line velocity; }\end{array}$ \\
\hline 5 & & $\begin{array}{l}\text { - Project based organization cannot have legacy equipment; i.e., need } \\
\text { technology organization to own the equipment; e.g., LDUA, LR-51, and } \\
\text { pit viper }\end{array}$ \\
\hline $5 \mathrm{~A}$ & & $\begin{array}{l}\text { - Better acceptance of the LDUA; i.e., Hanford use, amazing tool used } \\
\text { successfully at two other sites }\end{array}$ \\
\hline 6 & & $\begin{array}{l}\text { - Set realistic and defensible safety requirements; e.g., not allowing bracing } \\
\text { on arm retrieval }\end{array}$ \\
\hline 7 & 2 & $\begin{array}{l}\text { - Investing in new ideas to feed the pipeline; e.g., SERDP funds small short- } \\
\text { term proof of concept }\end{array}$ \\
\hline 8 & & $\begin{array}{l}\text { - Not thinking that you can buy commercially off the shelf; e.g., FLYGT } \\
\text { mixers; bought off the shelf and then modified it }\end{array}$ \\
\hline 9 & 3 & $\begin{array}{l}\text { - Assessing technological maturity of equipment solutions; e.g., DST } \\
\text { annulus crawler; do more robust testing prior to deployment }\end{array}$ \\
\hline 10 & & $\begin{array}{l}\text { - Ownership and responsibility for project/program design and establishing } \\
\text { dividing lines }\end{array}$ \\
\hline
\end{tabular}

\begin{tabular}{|c|l|c|c|c|}
\hline \multicolumn{7}{|c|}{ NOMINAL GROUP TECHNIQUE (NGT) } \\
\hline \multicolumn{1}{|c|}{ WHAT COULD HAVE BEEN “DONE BETTER” } \\
\cline { 2 - 5 } Item & \multicolumn{3}{|c|}{ Total } & New \\
& \multicolumn{1}{|c|}{ Voints } & 3 & 10 & \\
\hline 1 & $4,3,3$ & 3 & 7 & \\
\hline 2 & $1,3,3$ & 5 & 19 & 4 \\
\hline 3 & $5,4,3,5,2$ & 9 & 32 & 1 \\
\hline 4 & $5,3,3,2,4,4,5,4,2$ & 6 & 12 & \\
\hline 5 & $3,5,1,1,1,1$ & 5 & 19 & 5 \\
\hline 6 & $2,4,5,3,5$ & 7 & 21 & 2 \\
\hline 7 & $3,5,1,3,4,1,4$ & 5 & 8 & \\
\hline 8 & $1,2,4,1$ & 8 & 21 & 3 \\
\hline 9 & $1,2,2,2,2,2,5,5$ & 5 & 16 & \\
\hline 10 & $4,4,1,2,5$ & & & \\
\hline
\end{tabular}




\section{NGT Review and Thoughts on the Results}

- Amazing: these votes hit all items

- $\quad$ Some items are more policy than perhaps EM-21 can implement, e.g., item 5

- \#5: has a lot of one votes

- There is a lot of inter-relationship between the 10 items

\section{MEMORIES}

- Requirements: Some inputs will need to be expanded; some inputs will be sub-elements of others and need to be combined

- Draft Plan

- 10 pages

- Define SST vs. DST retrieval requirements and challenges/gaps

$\checkmark$ Verify and validate “requirements”. Don't let the task be made more difficult than it really is

$\checkmark=$ Noted lesson learned and memory

\section{PATH FORWARD SUPPORT}

\begin{tabular}{|c|c|c|}
\hline WHAT & WHO & WHEN \\
\hline $\begin{array}{l}\text { 1. Support to Mike Rinker to edit the technical } \\
\text { requirements sections by function: } \\
\text { 1. Characterize tanks } \\
\text { 2. Access tanks } \\
\text { 3. Dislodge/mobilize waste } \\
\text { 4. Convey waste } \\
\text { 5. Transport waste }\end{array}$ & $\begin{array}{l}\text { Beric Wells } \\
\text { Peter Gibbons } \\
\text { Dennis Mullen } \\
\text { Brian Hatchell } \\
\text { Phil Gauglitz } \\
\text { Judith Bamberger } \\
\text { Harold Adkins } \\
\text { Adam Poloski } \\
\text { Mike Thien }\end{array}$ & $9 / 26 / 08$ \\
\hline $\begin{array}{l}\text { 2. Overall support to Mike Rinker to finalize the draft } \\
\text { plan format and content. }\end{array}$ & $\begin{array}{l}\text { Dennis Mullen } \\
\text { Brian Hatchell } \\
\text { Phil Gauglitz } \\
\text { Judith Bamberger } \\
\text { Carl Baker } \\
\text { Beric Wells }\end{array}$ & 9/29/08 \\
\hline
\end{tabular}




\title{
APPENDIX C
}

\section{Agenda, Opening Remarks, Retrieval Function Diagram, and Attendance Roster}

\author{
EM-21 TANK WASTE RETRIEVAL STRATEGIC PLANNING SESSION \\ September 11, 2008, ETB Wenatchee River Room
}

Purpose: Define top level retrieval requirements, exchange lessons learned, and develop a path forward to support a strategic business plan and future work

- Define retrieval requirements and top challenges

- Exchange lessons learned (Complex-wide retrieval and technology efforts)

- Develop the next steps for success

\section{AGENDA}

8:30 - Welcome/Purpose, Introductions, Agenda, and Safety Topic

- Opening Remarks and Key Drivers

9:00 - Define Tank Waste Retrieval Requirements

- Overview retrieval functions and flow

- Define top-level requirements

- Identify current challenge areas

10:15 - BREAK

10:30 - Conduct Lessons Learned

- Identify what has "Worked Well"

- Define what could be "Done Better"

- Prioritize/rank lessons

\section{2:00 - WORKING LUNCH}

12:30 - Review/Validate Requirements and Lessons

- Overview and confirm requirements and challenges

- Validate and confirm lessons learned

- Upgrade requirements, lessons, and needs, as required

1:30 - Develop Path Forward Implementation Plan

- Discuss follow-on needs and efforts needed (What and When)

- Define actions and leaders, as required (Who, What, and When)

2:00 - Finish Session with a Round Robin Closeout

- Last minute items

- Meeting Utility 


\section{EM-21 TANK WASTE REIRIEVAL FAST DIAGRAM}

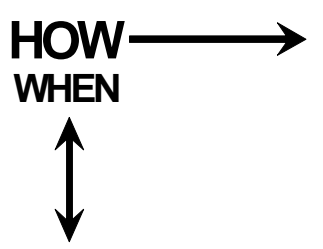

\begin{tabular}{|c|c|c|}
\hline Utilize & Facilitate \\
Previous & $\begin{array}{c}\text { Support } \\
\text { Technology } \\
\text { Tank Focus } \\
\text { Solutions \& } \\
\text { Area Work }\end{array}$ \\
Deployment
\end{tabular} $\begin{gathered}\text { DOE, Operators, } \\
\text { Technologists \& } \\
\text { Stakeholders }\end{gathered}$

\section{DESIGN OBJECTIVES}
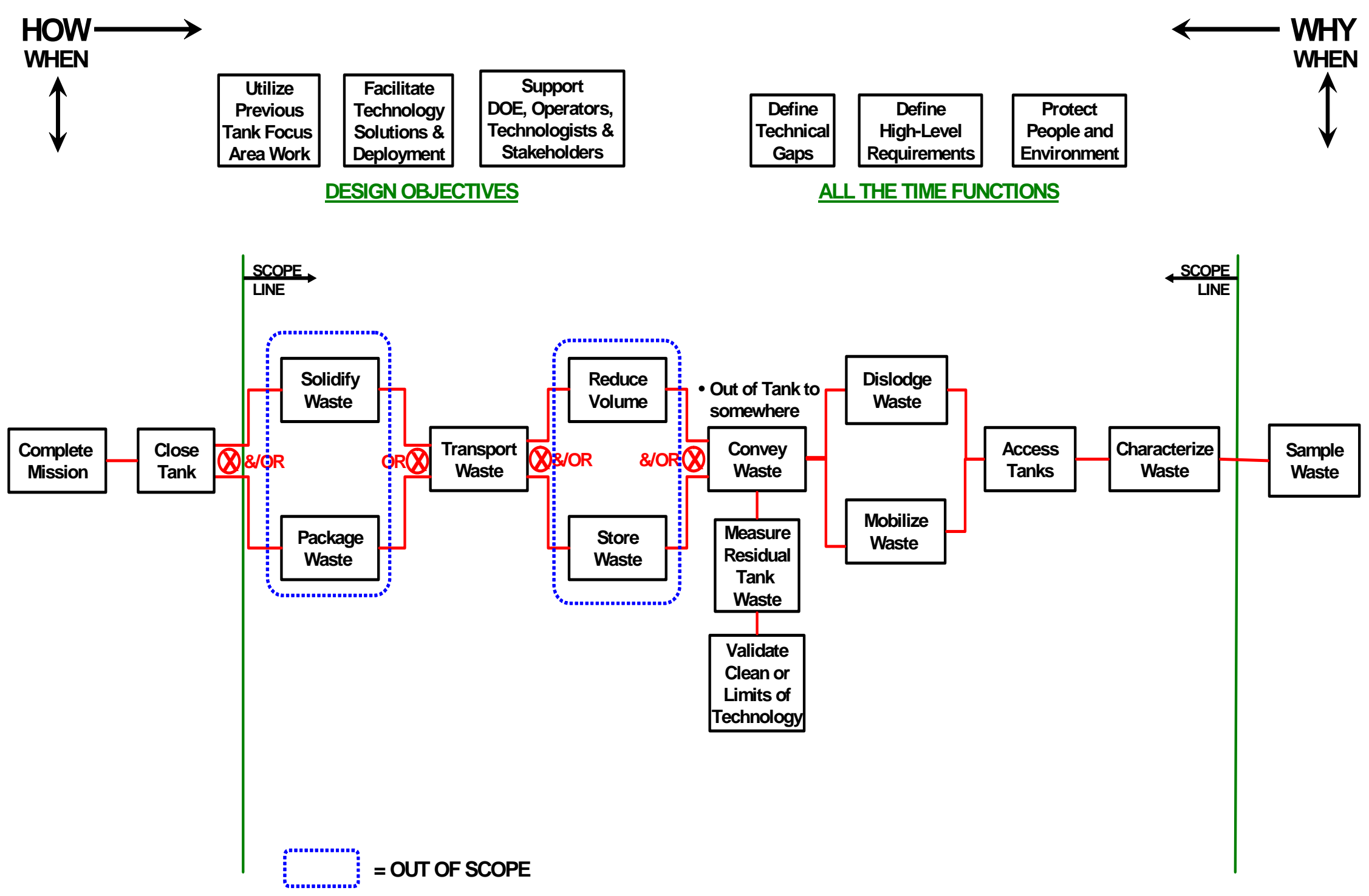


\section{OPENING REMARKS}

- Thank you for your time, attendance, and effort on this initiative

- 2002: The EM-50 and the Tank Focus Area efforts ended

- 2008: DOE-HQ EM-21 Office of Technology and Engineering - Established a Retrieval and Closure initiative to develop a Retrieval Knowledge Center Strategy Plan

- $\quad$ Led by Steve Krahn, established a laboratory team with focus on Hanford and SRS tanks; with other tank sites, as appropriate

- Sharon Marra of SRNL will be a primary lead to Mr. Krahn, Mike Rinker of PNNL will support Sharon

- Steve's vision

- Grow a program with visibility on tank retrieval requirements, technical gaps, databases, exchange lessons, and facilitate solutions in support of DOE, Tank Farm operations, and technologists

- Leverage previous TFA work

- You were asked/selected to support this effort today and in the future based on your past work/experience, education, and needed creativity and input

- This is an opportunity, thanks

- May not want to include close tank requirements today; however, we need to keep these requirements in mind as we proceed

\begin{tabular}{|c|c|c|}
\hline \multicolumn{3}{|c|}{$\begin{array}{c}\text { EM-21 Tank Waste Retrieval Requirements } \\
\text { Strategic Planning Session } \\
\text { Attendance Roster } \\
\text { September 11, 2008 } \\
\end{array}$} \\
\hline Name & Phone & Organization/Discipline \\
\hline Mike Rinker & $375-6623$ & PNNL - EM-21/Program Manager \\
\hline Kayle Boomer & $372-3629$ & CH2M - Technical Integration Program \\
\hline Mike Thien & $372-3665$ & CH2M - Technical Integration \\
\hline Blaine Barton & $376-5118$ & CH2M - Retrieval \\
\hline Phil Gaugliltz & $372-4665$ & PNNL - Fluid \& Computational Engineering \\
\hline Beric Wells & $375-6671$ & PNNL - Fluid \& Computational Engineering \\
\hline Carl Baker & $375-2724$ & PNNL - Robotics/Systems Manager \\
\hline Andrew Fellinger & $803-725-5705$ & SRNL - SRNS \\
\hline Harold Adkins & $372-6629$ & PNNL - Fluid \& Computational Engineering \\
\hline Paul Scott & $372-6223$ & PNL \\
\hline Brian Hatchell & $375-2762$ & PNNL Robotics/Medical Systems \\
\hline Judith Bamberger & $375-3898$ & PNNL Fluids \\
\hline Dennis Mullen & $375-2395$ & PNNL \\
\hline Peter Gibbons & 539-3184 & PW Gibbons Inc. \\
\hline
\end{tabular}




\section{Appendix B}

EM-21 Tank Waste Retrieval Requirements Strategic Planning Session at Savannah River Site 



\section{EM-21 Tank Waste Retrieval Requirements Strategic Planning Session At Savannah River Site}

October 22, 2008

Requested by: $\quad$ Drew Fellinger, Remote \& Specialty Equipment Savannah River National Laboratory Aiken, South Carolina

Facilitated by: $\quad$ Richard Harrington, CVS

CH2M HILL

Richland, Washington 


\section{TABLE OF CONTENTS}

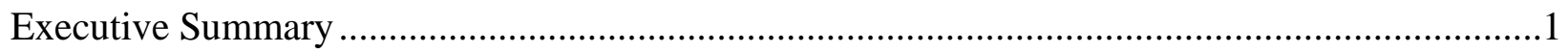

Appendices

A. Tank Waste Retrieval Technical Requirements and Challenges .........................................3

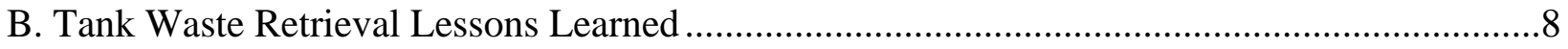

C. Agenda, Opening Remarks and Attendance Roster ........................................................13 
EM-21 is the Waste Processing division of the Office of Engineering and Technology (OET), within the U.S. Department of Energy's (DOE's) Office of Environmental Management (EM). In August of 2008, EM-21 began a Retrieval and Closure initiative to develop a Retrieval Knowledge Center Strategy and work plan. Part of this effort focuses on a tank waste retrieval scope lead by Andrew Fellinger of Savannah River National Laboratory (SRNL) and Mike Rinker of Pacific Northwest National Laboratory (PNNL). In support of this effort a facilitated workshop was requested to define top-level retrieval requirements and challenges, lessons learned, and path forward to support the EM-21 strategic business plan and future work.

The workshop was conducted in two parts to facilitate site participation. Part one was held on September 11, 2008, in the Hanford PNNL Environmental Technology Building. The multidisciplinary team included engineering and scientific representatives from PNNL, SRNL, and CH2M HILL. Part two was held on October 22, 2008 at the Aiken County Research Park. This document captures the content of the part two workshop. Appendix C contains the workshop session agenda, opening remarks, and attendance roster.

\section{Session Results}

The session was successful in the teams' development of current tank waste retrieval top-level requirements and challenges (Appendix A), waste retrieval lessons learned (Appendix B), and a path forward directed at utilizing these results to upgrade and finalize a fiscal year-end submittal in support of the EM-21 Retrieval Knowledge Center Strategy and Work Plan.

The top-level requirements and lessons learned were based on current Hanford and Savannah River site operations mission experience and future needs, by leveraging waste retrieval operations and Tank Focus Area (TFA) experience and completed work.

\section{Session Process}

The facilitator opened with the session purpose, agenda, safety topic, team member introductions, and review of a high-level retrieval function diagram to focus the process. Drew Fellinger and Mike Rinker delivered opening remarks that centered on thanking the team members for their support to fulfill the EM-21 strategy and vision for a technical database with top-level tank waste retrieval requirements, technical gaps, and lessons to facilitate DOE, tank farm operators, and technology solutions.

The top-level requirements were defined from the teams' collective input in five retrieval functional areas. Afterwards, the team reviewed all the requirements and identified the top current technical challenges (i.e. technical gaps). The lessons learned were developed from the team's response to two questions: What has worked well and what could have been done better. The lessons learned focus was to leverage operations experience, TFA work and future needs. The team prioritized each set of lessons based on their positive impact for successfully fulfill the waste retrieval missions.

The session concluded with a round robin close-out where each member was engaged for any last minute items and meeting utility. In summary, the team felt the workshop was value-added.

\section{Facilitator Comments}

The team did an excellent job of staying focused on the session purpose and covering a lot of ground in a short one-day effort. Moreover, the multidisciplinary team consisted of senior-level 
professionals who represented actual tank waste retrieval operations experience to-date and leveraged TFA work and lessons learned. Special thanks to Mike Rinker and Drew Fellinger for their leadership in bringing together this multidisciplinary team of professionals who openly and actively exchanged past experience and defined the requirements and challenges to overcome for successful future waste retrievals. 


\section{APPENDIX A}

TANK WASTE RETRIEVAL

HIGH-LEVEL TECHNICAL REQUIREMENTS

AND

TECHNICAL CHALLENGES 
Five Functional Areas:

\section{Characterize Waste, 2. Access Tanks, 3. Dislodge/Mobilize Waste, 4. Convey Waste and 5. Transport Waste}

\section{CHARACTERIZE WASTE}

* Rheology

- Speciation

* Represents entire tank and residual waste

- Particle size \& density

- Settling rate

- Solubility

* Volume \& mass

- Fraction of sludge vs. salt

- Corrosion characteristics

- History of process

- Sample waste

* Measurement and analysis

* Top level challenges 


\section{ACCESS TANKS}

* Available risers

* Internals (tank)

- Waste levels

- What goes in has to come out

- Including what is already in there (eg: long length equipment)

- The dose, exposure rate; potential

- Visibility

- Interferences (external)

- Must be integrated with existing SSC's and operations procedures

- Maintain tank integrity

- Structural

- Rad exposure to personnel

- Limitations of disturbing waste (eg: hydrogen release)

- Utilities

- Tank leak history

* Technology to navigate and or remove internals

* Top level challenge

\section{DISLODGE/MOBILIZE WASTE}

- Effective cleaning radius

- Where to send it (ie: downstream impacts)

* Minimize secondary waste generation

- Energy requirements

- Avoid aerosols and/or hepa plugging

- Maintain confinement ventilation

- Maintain tank integrity

- Understand flammable gas generation

* Maximize ability to get all waste to the transfer system

- Mitigate plugging

* Maintain waste processing capabilities down stream

- Maintain criticality control

- Must be able to remove or suspend equipment used

* Top level challenge 


\section{CONVEY WASTE}

- Rheology

- Settling velocities

- Height and distance

- Particle size and density

- Evaluate effectiveness in real rime

- Waste form virility (ie. fragile)

- Shielding requirements and dose

- Solubility and precipitations

- Mixing needs/properties and or dilution

- How low or level of tank pump needs

* Location of conveying device \& interfaces (ie: internals)

- Erosion and integrity of retrieval equipment

- Facilitate various waste forms and or debris (eg: hard hat, gloves, reel time, sample bottles, etc)

- Emissions from conveyance systems

- Capability, integration, and compliance with existing SSC's

- Flushing system and cleaning requirements

* Viable technology and design life

- High rad

- Robust

- Spare parts and/or containment to protect and/or maintain

* Estimate residual tank waste

- Including characterization

- Must be able to remove or suspend equipment used

* Top level challenge 


\section{TRANSPORT WASTE (From DST and/or Type III Tanks)}

- Dose

- Containment (ie: line within a line; primary and secondary)

- Rheology

- Particle size and density

* Avoid system/line plugging

* Recovery requirements (eg: unplugging)

- Design pressure/needs

- Facility/systems interfaces and integration

- Self draining

- Leak detection

- Prevent siphoning

- Flushing needs/requirements

- Material accountability

- Erosion and integrity of the piping system

- Environmental controls

- Maintain criticality control

* Compatibility on the receiving end (ie: destination)

* Top level challenge 


\section{APPENDIX B}

\section{TFA AND TANK WASTE RETRIEVAL LESSONS LEARNED}




\section{What Worked Well and What Could Have Been Done Better}

\begin{tabular}{|c|l|}
\hline \multicolumn{2}{|c|}{ WHAT WORKED WELL } \\
\hline Item & \\
\hline 1 & Management and priority on tank 17 \& 20 retrieval and closure \\
\hline & Transporting sludge from the tank to sludge washing (ie: sludge batching) \\
\hline & Using risk assessment performance assessment to determine end state as clean \\
\hline 4 & Steam jet \\
\hline 5 & Testing SSC's in a simulant outside a rad environment (ie cold testing) \\
\hline 5 A & Adequate testing and equipment mock-up \\
\hline 7 & $\begin{array}{l}\text { Supernate recycle system to minimize secondary waste generation } \\
\text { passing knowledge } \\
\text { including technology }\end{array}$ \\
\hline 8 & SRNL support \\
\hline 10 & $\begin{array}{l}\text { Simple tools } \\
\text { (eg: well pump) }\end{array}$ \\
\hline 11 & $\begin{array}{l}\text { Tank 17 \& 20 sampling } \\
\text { Teaming and quick deployment of existing and new technology }\end{array}$ \\
\hline 12 & Projectizing, with incentives, retrieval campaigns (ie: tanks 5,6, 12, 13, 18, 19, etc) \\
\hline
\end{tabular}

= Most significant impact on the future retrievals and the balance will follow 


\begin{tabular}{|c|c|c|}
\hline \multicolumn{3}{|r|}{ WHAT COULD HAVE BEEN “DONE BETTER” } \\
\hline Item & $\begin{array}{l}\text { New } \\
\text { Rank }\end{array}$ & \\
\hline 1 & 2 & $\begin{array}{l}\text { - Identify closure criteria } \\
\text { - Maintain the criteria }\end{array}$ \\
\hline $1 \mathrm{~A}$ & 3 & $\begin{array}{ll}\text { - } & \text { Common/complex wide closure criteria } \\
\text { - } & \text { Mitigate/prevent law suits } \\
\text { - Including a technical and justifiable decision point to "leave waste in } \\
\text { place” }\end{array}$ \\
\hline 2 & & - Heal removal \\
\hline $2 \mathrm{~A}$ & & $\begin{array}{l}\text { - Transfer system to the waste in an obstructed tank } \\
\text { - } \text { Remove constraint of a single (pump suction) transfer point }\end{array}$ \\
\hline 3 & & - Understanding the chemistry of dissolution \\
\hline 4 & & $\begin{array}{l}\text { - Early integration of the project team } \\
-\quad \text { SRNL people to the project team }\end{array}$ \\
\hline 5 & 1 & $\begin{array}{l}\text { - Getting a management champion } \\
\text { - Maintain a constant champion }\end{array}$ \\
\hline 6 & 4 & - A through understanding of what has been done complex wide \\
\hline $6 \mathrm{~A}$ & & $\begin{array}{l}\text { - Better integration and working between the sites on resolving common } \\
\text { issues or problems } \\
\text { - } \quad \text { (eg: heel removal and chemical cleaning - unique and common from one } \\
\text { site to another) } \\
\text { - } \quad \text { Initiate integration with appropriate site point of contacts }\end{array}$ \\
\hline 7 & & _ Sample analysis \\
\hline 7A & 5 & $\begin{array}{ll}- & \text { Faster turnaround on sample analysis } \\
\text { - } & \text { (eg: ISDP qualification } 2.5 \text { to } 3 \text { months } \\
\end{array}$ \\
\hline 7B & & - Improve detection limits \\
\hline $7 \mathrm{C}$ & & - Cross contamination \\
\hline 8 & & $\begin{array}{l}\text { - } \quad \text { Collecting, retrieving and performance documenting, retrieval data } \\
\text { - } \quad \text { Demonstrate to removal to MEP (material extent practical/possible) } \\
\text { - } \quad \text { Withstand/successful legal scrutiny }\end{array}$ \\
\hline 9 & & $\begin{array}{l}\text { - Utilize and adapt to commercial practices } \\
\text { - Note: Consider other industries eg: ship bulk technologies }\end{array}$ \\
\hline 10 & & - Continuous recycle of supernate (eg: Hanford tank C-106) \\
\hline
\end{tabular}




\begin{tabular}{|c|l|c|c|c|}
\hline \multicolumn{5}{|c|}{ NOMINAL GROUP TECHNIQUE (NGT) } \\
\cline { 2 - 4 } WHAT COULD HAVE BEEN “DONE BETTER” \\
\cline { 2 - 4 } Item & \multicolumn{1}{|c|}{ Votes/Points } & Total & New \\
& \multicolumn{1}{|c|}{ Rank } \\
\hline 1 & $4,4,2,2,4,1,5,1,5,4,5,5,4$ & 13 & 46 & 2 \\
\hline 2 & $3,3,5,5,5,1,2,3,4,5,5,4$ & 12 & 45 & 3 \\
\hline 3 & $3,4,2$ & 3 & 9 & \\
\hline 4 & 2 & 1 & 2 & \\
\hline 5 & $2,5,5,2,3,4,4,2,3,5,5,5,2$ & 13 & 47 & 1 \\
\hline 6 & $1,3,3,2,3,4,3,4,4$ & 9 & 27 & 4 \\
\hline 7 & $2,1,2,3,1,2,1,3$ & 8 & 15 & 5 \\
\hline 8 & $3,2,1,1,1$ & 5 & 8 & \\
\hline 9 & $4,1,1,3,1$ & 5 & 19 & \\
\hline 10 & 1 & 1 & 1 & \\
\hline
\end{tabular}

\section{NGT Review and Thoughts on the Results}

- Ten items: somewhat of a split between getting the job done in the field vs. the regulatory and or support functions.

- Surprised that a chemical dissolution didn’t score higher; this is key in two tanks we are working now.

- Management champion is very important, but we may have little impact/influence on it.

- I connect management champion(s) as a part of the priority.

- We will learn a lot after we close a tank(s): This group needs to get back together to exchange and use this input.

- We need to get this right.

- A lot to gain or lose

- Look at \#8: We don't know yet how important this may be. (ie: we maybe one lawsuit away!!) Although, I wish we didn’t require the use of lawyers to complete this important work. 


\section{MEMORIES}

- Remember oversight \& stakeholders

Key players

Stakeholders (public, etc.)

NRC

EPA

DHEC

- $\quad$ Be aggressive to close tanks over the next 8 - 10-years

- No two tanks are the same

- Keys to success

o Identify technologies used, benefits, time \& cost lessons

- Remember there will be dry retrievals

- Cleaning annulus area on leakers

- Funding/budget (ie: money - valid memory)

- Consider robotic platform to serve several requirements and challenges

PATH FORWARD SUPPORT

\begin{tabular}{|l|l|c|}
\hline \multicolumn{1}{|c|}{ WHAT } & \multicolumn{1}{c|}{ WHO } & WHEN \\
\hline Characterize Waste & Michael Poirier & $10 / 31 / 08$ \\
\hline Access Waste & Rick Minichan & $10 / 31 / 08$ \\
\hline Dislodge/Mobilize Waste & Tommy Caldwell & $10 / 31 / 08$ \\
\hline Convey Waste & Noel Chapman & $10 / 31 / 08$ \\
\hline Transport Waste & Noel Chapman & $10 / 31 / 08$ \\
\hline Lessons Learned & $\begin{array}{l}\text { Bruce Martin/Eloy } \\
\text { Saldivar }\end{array}$ & $10 / 31 / 08$ \\
\hline Collect, final edit and converge with Hanford & $\begin{array}{l}\text { Mike Rinker/Drew } \\
\text { Fellinger }\end{array}$ & $11 / 7 / 08$ \\
\hline
\end{tabular}




\section{APPENDIX C}

Agenda, Opening Remarks, Retrieval Function Diagram, and Attendance Roster 


\section{EM-21 TANK WASTE RETRIEVAL REQUIREMENTS PLANNING SESSION \\ 999-W \\ $3^{\text {rd }}$ Floor Conference Room}

October 22, 2008

Purpose: Define top level retrieval requirements, exchange lessons learned, and develop a path forward to support a strategic business plan and future work

- Define retrieval requirements and top challenges

- Exchange lessons learned (Complex-wide retrieval and technology efforts)

- Develop the next steps

\section{AGENDA}

8:30 - Welcome/Purpose, Introductions, Agenda, and Safety Topic

- Opening Remarks and Key Drivers

9:00 - Define Tank Waste Retrieval Requirements

- Overview retrieval functions and flow

- Define top-level requirements

- Identify current challenge areas

10:15 - BREAK

10:30 - Conduct Lessons Learned

- Identify what has "Worked Well"

- Define what could be "Done Better"

- Prioritize/rank lessons

12:00 - WORKING LUNCH

1:00 - Review/Validate Requirements and Lessons

- Overview and confirm requirements and challenges

- Validate and confirm lessons learned

- Upgrade requirements, lessons, and needs, as required

2:00 - Develop Path Forward Plan

- Discuss follow-on needs and efforts needed (What and When)

- Define actions and leaders, as required (Who, What, and When)

3:00 - Finish Session with a Round Robin Closeout

- Last minute items

- Meeting Utility 


\section{EM-21 TANK WASTE RETRIEVAL FAST DIAGRAM}

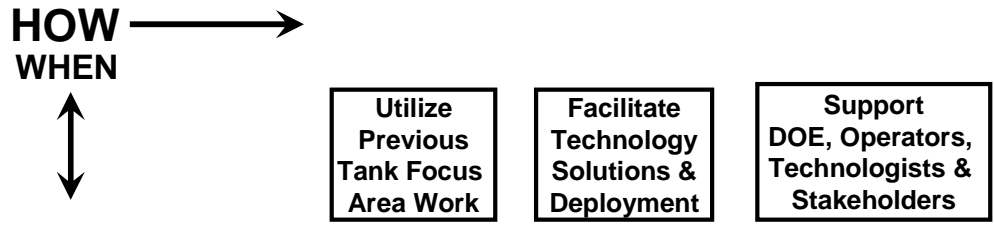

DESIGN OBJECTIVES

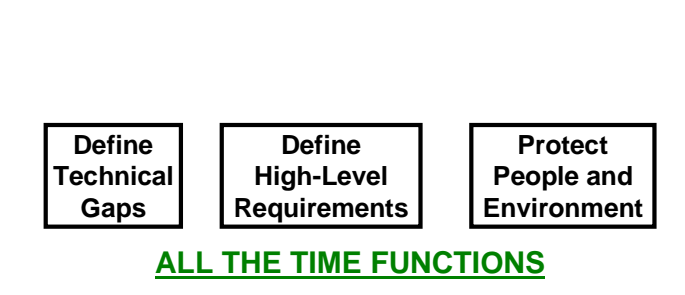

$\longleftarrow$ WHY

WHEN

$\uparrow$

ALL THE TIME FUNCTIONS

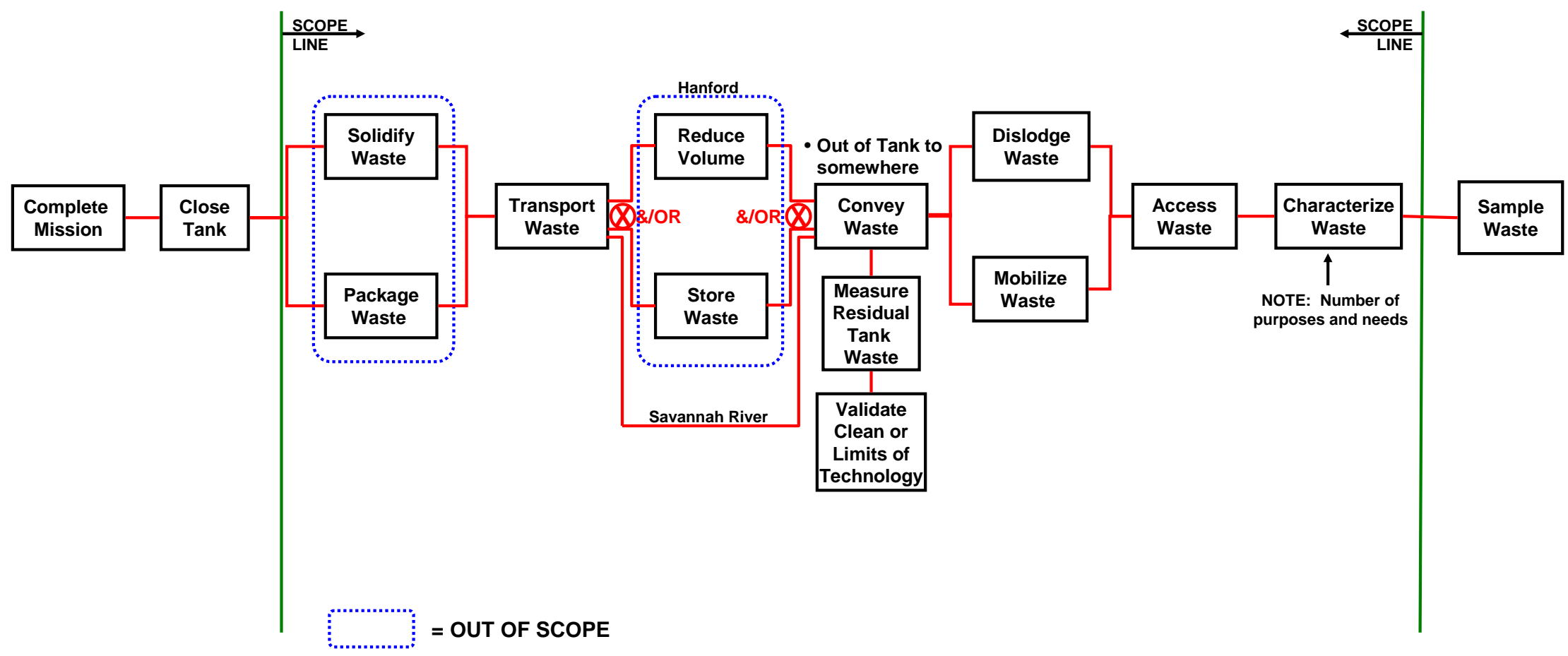




\section{OPENING REMARKS}

- Thank you for your time, attendance, and effort on this initiative

- 2002: The EM-50 and the Tank Focus Area efforts ended

- 2008: DOE-HQ EM-21 Office of Technology and Engineering - Established a Retrieval and Closure initiative to develop a Retrieval Knowledge Center Strategy Plan

- $\quad$ Led by Steve Krahn, established a laboratory team with focus on Hanford and SRS tanks; with other tank sites, as appropriate

- Sharon Marra of SRNL will be a primary lead to Mr. Krahn, Mike Rinker and Drew

Fellinger are co-PIs and will support Sharon

- Steve's vision

- Grow a program with visibility on tank retrieval requirements, technical gaps, databases, exchange lessons, and facilitate solutions in support of DOE, Tank Farm operations, and technologists

- Leverage previous TFA work

- You were asked/selected to support this effort today and in the future based on your past work/experience, education, and needed creativity and input

- This is an opportunity, thanks

- May not want to include close tank requirements today; however, we need to keep these requirements in mind as we proceed

\begin{tabular}{|l|c|l|}
\hline \multicolumn{3}{|c|}{$\begin{array}{r}\text { EM-21 Tank Waste Retrieval Requirements } \\
\text { Strategic Planning Session } \\
\text { Attendance Roster } \\
\text { October 22, 2008 }\end{array}$} \\
\hline \multicolumn{1}{|c|}{ Name } & \multicolumn{1}{c|}{ Ohone } & \multicolumn{1}{c|}{ Organization/Discipline } \\
\hline Mike Rinker & $375-6623$ & PNNL - Program Manager \\
\hline Rick Minichan & $803-725-2271$ & SRNS - SRNL \\
\hline Noel Chapman & $803-952-3806$ & WSRC/LWO Engineering \\
\hline Dan McCabe & $803-725-8238$ & SRNS - SRNL \\
\hline Andrew Fellinger & $803-725-5705$ & SRNS - SRNL \\
\hline Bruce Martin & $803-208-2902$ & SRNS - ME \\
\hline Eloy Saldivar & $803-208-0245$ & SRNS - ME \\
\hline Tommy Caldwell & $803-208-8430$ & WSRC/ChE/MHE \\
\hline Tom Nance & $803-725-5842$ & SRNS/SRNL/C\&SS \\
\hline Eric Kriikku & $803-725-1433$ & SRNS - SRNL/EE \\
\hline Heather Burns & $803-819-8469$ & SRNS - SRNL - E\&CPT \\
\hline Erich Kessler & $704-799-2707$ & NVE/Engineering \\
\hline Talmadge Griffie & $704-799-2707$ & NVE/Engineering \\
\hline Michael Poirier & $803-725-1611$ & SRNS - SRNL - ChE \\
\hline Mark Mahoney & $803-208-3572$ & WSRC/Engineering \\
\hline
\end{tabular}




\section{Appendix C}

\section{EM-21 - "Retrieval Technology Program Needs and Recommendations" by Pete Gibbons}



EM-21 - Input to "Retrieval of HLW Technical Requirements"

PWGibbons Inc

\section{Technology Gaps}

Several technology gaps stand in the way of a complete retrieval tool box that will cover the spectrum of waste forms (soft, hard, soluble, etc.) and tank conditions (Internal obstructions, small access ports, leaking tanks, etc.).

Many retrieval system types have been tested over the years that have applicability for most of the existing conditions. They would, however, require extensive development and user site investment to become field deployable units. In light of limited budgets for EM technology development and at the HLW sites for deployment, availability of funds is a major driver of both technologies and tanks selected for retrieval. As a result, direct site support technology work must be accepted by the Site as beneficial to add into their waste retrieval schedule. Long lead projects that anticipated a place in tank remediation have had a poor track record in being taken up for use.

Therefore the EM-21 development work should be timely and result in answering questions or providing technology that can be used or "tested" in the next few years as part of a waste retrieval operation at a given site.

This approach limits development to activities that are coupled to Site plans. Future gaps should also be investigated so as to be prepared for the next stage of retrieval activities as the "limits of technologies" are reached. These should, however, be modest in scope, proving retrieval principles and building up a data base so as to provide the Sites with a basis for selection of the next technologies.

\section{Technology workshops}

Depending on the participants, workshops can be a very valuable tool on several fronts.

1. Technology needs or gaps. Meeting with site technical staff can yield a strong insight into the limitations of existing technologies experienced by the sites.

The warning here is that the desires of technical staff does not necessarily reflect site management support or the likelihood of eventual deployment of a proposed technology. The likelihood of deployment in the next several years needs to be determined and considered.

2. Cross-Site Integration and Technical Information exchange. These meetings keep technical staff from several sites with similar issues up-to-speed on progress and challenges at other sites. The cross-site experiences and insights provide valuable suggestions as to how experiences and planning at one site may be of use at another. Successful use of a technology at one site may also help break through the "Untried Method" barrier at another site. 
EM-21 - Input to "Retrieval of HLW Technical Requirements"

PWGibbons Inc

3. Technology Interface needs. Exchanges with site and laboratory technical staff from disciplines with a handoff functions such as retrieval to pretreatment provide an opportunity to identify requirements that may have been overlooked or expectations that are at cross purposes. An example of this is the pretreatment chemist's expectation of a pure feed stream for his resin column from retrieval whereas retrieval expects to retrieve waste indiscriminately. The function of segregating and clarifying the waste stream for pretreatment may not be in either's plans.

4. Available commercial remediation technologies. Bringing technology vendors together with Site technical staff and laboratory staff serves to explain the challenges to the vendors who in-turn present their products, where and how they have been used commercially and suggest how they might be used to solve HLW Site problems without extensive development.

\section{$\underline{\text { Retrieval Knowledge Center }}$}

Over the last 20 years many retrieval technologies have been developed and tested under various conditions. In addition, high level radioactive waste retrieval operations have taken place across the US DOE HLW Complex and around the world. Access to past experiences will help owners seeking to remediate radioactive waste tank to learn available lessons from past work, both successful and unsuccessful.

Updating and reorganizing the old Tanks Focus Area Tanks Technology Guide to include developments since 2002 would be valuable. In addition, judgment comments pro and con with rationales on articles and technologies by technical staff with experience in each area would increase the value of these data for future use.

\section{Barriers to Technology}

While many technologies have been brought to bear on the problem of HL Waste tank remediation, often conditions exist on the different sites that foreclose options that have the potential to save money in the long run and to drastically reduce worker exposure. One such condition is the lack of a mechanism for ownership of equipment outside of the framework of a particular project. This prevents the use of "multi-use equipment" such as a machine to remotely access cleanout and setup piping pits for transfer. A concern at the sites includes the higher short-term costs in the current year override promises of savings in later years and how the current year's award fee is structured.

\section{$\underline{\text { Technology Needs }}$}

Technology needs are highly dependant on the point of view. Laboratory staff need numerical data so calculations to predict equipment behavior can be made. Engineers need relative performance comparison data for the same purpose. The truth is that getting representative numerical data is unlikely. Anything that increases the risk of 
EM-21 - Input to "Retrieval of HLW Technical Requirements"

PWGibbons Inc

stopping retrieval such as a spill while handling a sample will be avoided. For this reason drawing a sample from a waste transfer line to monitor transfer chemistry is extremely unlikely. A strategy must be struck that works the system to get needed data with a minimal impact of site operations. One way is to observe equipment performance in the field and duplicate it in the laboratory in order to draw out performance data and infer waste characteristics.

Development of retrieval technologies should be incremental, starting with simple and cheap and progressing to more capable and expensive as needed, with the cost basis data being accumulated with deployment experience. It may be useful to overshoot a bit on the development side if it's done early enough that it shows that we can quit major $R \& D$ fairly early and get all the retrieval done with a limited and relatively inexpensive box of tools. 
EM-21 - Input to "Retrieval of HLW Technical Requirements"

PWGibbons Inc

1. INTRODUCTION

\section{TANK WASTE RETRIEVAL PRIMARY FUNCTIONAL REQUIREMENTS}

\subsection{WASTE CHARACTERIZATION}

2.1.1. Definition of the waste retrieval characterization function. What is characterization as related to retrieval? Note: This is more of a definition of what characterization is and what it means for retrieval.

The purpose of the Characterize Waste function is to understand the waste properties that are necessary for waste retrieval. Needed data include the current inventory of solids, liquids, and gases; and their physical, chemical and radiological properties, including both the mobilized and in-situ conditions of the waste. Uses for these data include selection of retrieval equipment types and compatibility with processes such as pipeline transfer and meeting down-steam chemistry requirements.

2.1.2. Characterization Scope Note: This is meant to be more of discussion as to the range of characterization that is necessary for retrieval.

Tank waste characterization data is obtained by one of the following methods.

- Historical chemical process data from the generation of the waste

- Chemical data from direct waste core samples

- Chemical data from small grab samples

- Physical data of in situ properties obtained by direct measurement.

- Physical data obtained in the laboratory from waste samples.

- Physical data of in situ properties inferred from the core sampling process

- Physical data of in situ properties inferred from the installation of equipment, such as a pump, into a body of waste.

- Physical data of in situ properties inferred from the performance of waste mobilization activities including mechanical, hydraulic and chemical.

- Physical data of waste slurry properties inferred from the performance of waste mobilization, conveyance and transfer activities.

Inferred data is emphasized as the availability of a tank and funding for characterization are quite limited. In addition, sampling waste is inherently risky from a spill or contamination incident standpoint and is, therefore, minimized in site operations planning. As a result the strategy of taking measurements during planned in tank operations is likely to yield a significant portion of available characterization data.

2.1.3. Primary Characterization requirements.

2.1.3.1.Solid properties

- Density of particles, bulk waste and post-dislodging slurries for conveyance system selection and design. 
EM-21 - Input to "Retrieval of HLW Technical Requirements"

PWGibbons Inc

- Rheological Properties in situ and as modified by candidate dislodging processes for dislodging and mobilization system selection and design. Macroscopic in-situ waste conditions unidentified by conventional waste characterization may have the potential to significantly impact retrieval operations.

- Measure the large/dense particles. These particles tend to remain behind due to solids pumping limitations. Quantification of large/dense particulates is needed to efficiently retrieve waste to acceptable levels.

- In-situ conditions (e.g., monolithic waste forms). The macroscopic characteristics of waste bodies and volumes must be understood. For example, large "popsicles" hanging on in-tank hardware will present different risks and challenges to the dislodging mechanism and the deployment platform than would the same solid material deposited in a crust over sludge or as a heel on the tank floor.

\subsubsection{Chemical properties}

- Waste compatibility with downstream processes.

- Solubility. In non-leaking tanks, solution methods can be very effective to dislodge the wastes and make them readily conveyed; however there are associated risks and complications. Some particular problems include gelation due to downstream temperature or chemistry/concentration changes, concentration of less-soluble solids, and managing increased volumes of solvent.

\subsubsection{Secondary Characterization requirements.}

2.1.4.1. Solid Properties

- Thorough sampling of all the waste volume in each tank is required, to the extent that the retrieval planning will be fully cognizant of the range and distribution of particle sizes, densities, etc.

- Current Hanford waste characterization provides insight into the waste's solid properties. However, there are significant portions of the waste which remain relatively uncharacterized (e.g., less than $20 \%$ of the Hanford undissolved solids inventory by mass has been rheologically characterized). The significance of the solid properties to waste retrieval requires that the solid properties are quantified. Given the complexity of the interaction of the solid properties and the broad spectrum of wastes, characterization sufficient for quantification of the pertinent solid properties is required.

\subsubsection{Chemical properties}

The chemical properties of the total waste inventory must be quantified for retrieval issues such as safety of operations, effectiveness of retrieval, and waste compatibility issues.

\subsubsection{Radiological properties}


EM-21 - Input to "Retrieval of HLW Technical Requirements"

PWGibbons Inc

The radiological properties of the total waste inventory must be quantified for retrieval issues such as safety of operations, effectiveness of retrieval, and waste compatibility issues.

2.1.4.4. Total Inventory of Solids liquids and Gases.

The total waste inventory must be quantified for storage and retrieval and safety.

\subsection{ACCESS WASTE}

2.2.1. Definition of the waste retrieval Access Waste function What is tank access as related to retrieval. As above, this would be more of a definition

Access waste provides for deployment of the retrieval equipment in such a manner that it can engage the waste for retrieval. This includes the tank penetrations that are required for insertion of waste retrieval equipment, specifically deployment of dislodging, mobilization and conveyance equipment. Tank access locations for waste retrieval may be existing penetrations or new ones installed specifically for retrieval operations. All tank access ports must maintain confinement of tank contents at all times.

2.2.2. Extent of Access Waste. This would be more of a description of what has been typically done for tank access in the past and what kinds of difficulties this makes.

With the exception of solution methods (not suitable for leaking tanks and possibly impractical for others depending on downstream chemistry and volume constraints), all known retrieval methods require physical access for introduction of equipment into the tanks. In some cases existing fairly small diameter (12 inches) risers are adequate - sluicing or borehole miner systems (and associated conveyance pumps can (somewhat hypothetically) operate through several small risers (if several are available) to retrieve a large fraction of waste in a tank. At the other extreme, introducing robust crawlers or large, powerful robotic arms will require one or more correspondingly large risers to deploy all the required equipment and to reach wastes in all areas of the tank. Existing tank access risers that are available for retrieval use tend to be small (12 inches in diameter), though some risers are 30 to 40 inches in size. Also, the location of available risers may not be optimal for retrieval operations. For example, many of the Hanford Single Shell tanks have a dish bottom necessitating waste scavenging pumping take place near the center of the tank. Currently, most retrieval systems are designed to fit through existing risers. This limits the type placement of retrieval deployment systems that can be used. 
EM-21 - Input to "Retrieval of HLW Technical Requirements"

PWGibbons Inc

\subsubsection{Primary Tank Access requirements}

- Access penetration size - new or existing. When several candidate retrieval technologies are suitable for the waste forms found in a given tank, a trade study will be required to determine whether installing new penetrations make sense.

- Retrieval system deployment methods. Making informed deployment decisions will require some practical history with the technologies considered, including trading against the practical cost of installing new tank penetrations. Some technologies may be inexpensive to operate in nearly automated mode (easy waste, sound tanks) while others may require continuous involvement of skilled human operators (remotely operated equipment in challenging wastes and vulnerable tanks). The cost of requisite access enhancements will have to be factored into each technology selection, and should be based on real, demonstrated and refined cost figures, not on worst-case postulations.

- Maintain Tank integrity and confinement. The deployment system must not harm the tank's ability to store the waste and confinement must me maintained to limit air emissions.

\subsubsection{Secondary Tank Access requirements}

- Removal of hardware from existing tank penetrations.

Many existing tank penetrations have obsolete equipment installed in them. Removing these equipments is difficult and expensive and presents a disposal problem for the many tanks that contained mixed TRU and hazardous wastes.

- Approved processes and procedures.

Once a process such as adding a new tank penetration has a successful history, even at another HLW site, many barriers are removed that prevent implementation at another location.

\subsection{DISLODGE / MOBILIZE WASTE}

2.3.1. Definition of the waste retrieval dislodging and mobilization function. What do we mean by dislodge and mobilize waste Waste mobilization alters the waste form sufficiently for removal from the tank by the waste conveyance system. Often this is the formation of pumpable slurry.

Waste dislodging begins with a mass of solid waste. The process breaks portions of waste away from the mass so they can then be mobilized.

\subsubsection{Extent of Dislodge / Mobilize Waste.}

To be retrievable waste must be available to be removed from the tank by a pump or other equipment. Waste dislodging systems separate waste from the bulk deposits in a tank. Waste mobilization systems condition the waste to be conveyed out of the tank. Often the same equipment serves both purposes. Waste dislodging/mobilizing equipment can be categorized as global, directed, or local. 
EM-21 - Input to "Retrieval of HLW Technical Requirements"

PWGibbons Inc

Global methods, such as mixer pumps affect the tank waste volume as a whole. Targeted methods such as large sluicing jets direct their energy as a particular location but can de directed at most of the tank volume. Local methods such as blades or high pressure scarifiers must be placed directly at the waste being processed.

Since dislodging and conveyance must be integrated to achieve waste retrieval, the dislodging product must be compatible with the operating envelope of the conveyance system. Conveyance systems are rated in terms of solids characteristics, such as density, particle size distribution, and solids loading, and slurry characteristics, such as density, viscosity, coating properties. For example, if a waterjet nozzle is used to break up a layer of saltcake, the dislodged particles must not be too large or heavy for the conveyance system to retrieve. A simple approach to this problem might be to use a screen on the conveyance inlet to prevent large particles from entering the conveyance line, but this only defers the solution. Conveyance systems also work best if the solid loading is fairly constant. If the solid loading is low, the retrieval process is not efficient; if the solid loading is too high, plugging of the conveyance line is possible.

Bulk mixer pumps and low-pressure sluicing jets have been the primary waste mobilization method across the complex. The advent of leaking tanks and difficult wastes has led to exploration of alternate methods.

\subsubsection{Primary requirements for dislodging and mobilizing waste}

- Protect the tank - While in some cases the tanks may be vulnerable to specific types of damage, it should not be assumed that all tanks are so delicate. Furthermore, it should be kept in mind that the tanks do not need to be serviceable after they have been retrieved - they are destined to be closed permanently. So long as containment/confinement requirements are met, we should not impose overly onerous constraints on the methods developed and used to expedite the elimination of the present hazards.

- Minimize the addition of media (water) that will increase waste volume. Processes that use no consumable media are preferable. Processes that use recyclable media (preferably requiring minimal re-conditioning) would be favorable. Processes that use media that can be separated (evaporated water for example) are tolerable. Use of low water-addition high-pressure scarifiers is one approach.

- Overcome difficulties associated with non-homogeneous solids and high settling rate solids which tend to be passed over by pump suction flow.

- Leak Detection, Monitoring and Mitigation (LDMM). A plan for LDMM is required for each tank retrieval operation. It is possible that a high water retrieval system which is more likely to leak into the ground could be used if a sensitive leak detection system was in place.

- Mobilize enough waste to meet clean out criteria (360 cu ft max residual). This includes the requirement to access sufficient waste 
EM-21 - Input to "Retrieval of HLW Technical Requirements"

PWGibbons Inc

despite internal tank obstructions. Internal obstructions usually require a global approach which ignores the obstructions or a local approach which places the tool behind and around the obstructions.

\subsubsection{Secondary requirements for dislodging and mobilizing waste}

- Monitor mobilization progress (this may be of limited practical value unless the technology requires a significant volume of mobilized waste to be maintained to support the conveyance system.)

- Monitor tool and process conditions

- Measurable criteria that defines when you are good enough to convey and/or done

- Ventilation (maintain visibility, control flammable-gases, maintain allowable pressure range.)

- Flammable gas safety

- Removable, maintainable, disposable and/or repairable

\subsection{CONVEY WASTE}

2.4.1. Definition of the waste retrieval conveyance function. What do we mean by Convey waste? (i.e. out of the tank)

Waste conveyance lifts the mobilized waste up out of the tank. Typically the waste is handed off to local storage or transfer lines to remote storage. Conveyance is typically a pumping system but could include air lifts or mechanical conveyors. Together with the Dislodge/Mobilize function, the Convey function will retrieve waste from the SSTs to the extent needed for closure. The end state of the Convey Waste function is waste conveyed from the tank into a transfer line to the extent needed for closure.

\subsubsection{Extent of Convey Waste}

To date most retrieval conveyance has been by means of mechanical pumps drawing from a pool of slurry. The primary limitation of typical mechanical pumps is a limited suction velocity which tends to leave heavy (high settling rate) solids behind. This has been overcome in some cases using jet pumps, both steam and high pressure water-jet., have been effectively used at some sites. These have been the standard method for moving waste out of HLW tanks. More recent installation are primarily limited to mechanical pumps as they do not add liquids and do not press safety boundaries as high pressure systems do. Air-lift conveyance has been extensively tested as a low water, heavy-solids lifting conveyance method but safety and waste hand-off issues make this a significantly more expensive approach.

\subsubsection{Primary requirements for Waste Conveyance.}


EM-21 - Input to "Retrieval of HLW Technical Requirements"

PWGibbons Inc

- Capture waste - both bulk mobilized waste as well as big and/or dense particles.

- Leave incompatible waste behind (Inlet discriminator - may also have to segregate and isolate non-waste matter such as small ITH, debris, ...)

- Minimize volumetric increase such as due to waterjet driver.

- Conveyance rate compatible possibly with transport function.

- Compatible with balance of system(s) (up and down stream. Define whether the process should be continuous or batch, acceptable flow regimes.

- Meet lift requirements and discharge pressure (fluid/multiphase flow).

- Monitoring of retrieval completion

o Measure when done $<360$ cubic feet(elsewhere)

o Limits of technology

o Measure and/or confirm meets regulatory requirements (e.g., residual TRU) (also a general requirement - residue in tank and accumulations in the system)

\subsubsection{Secondary requirements for Waste Conveyance}

- Modify waste properties to enable waste capture. E.G -- Dissolve the particles or thicken the liquid to float the particles.

- Asses whether the hard to get particles can safely be left behind so as to avoid repeating the same problem in the destination tank.

- Monitor conveyed waste mass, volume, and material balance (i.e., properties). Accurately quantifying the mass of captured waste solids and liquid is difficult with existing instruments. Accordingly, improved instruments, dissolution/precipitation models, and analysis methods are needed to effectively monitor conveyed waste mass and volume.

- X-tank conveyance leak detection

\subsection{TRANSPORT WASTE}

2.5.1. Definition of the transport waste function

Waste Transport moves the waste from one tank to another usually pumped via transfer pipelines. The waste conveyance system is often used as the motive force for transfer.

\subsubsection{TRANSPORT WASTE FROM SSTs TO DSTs}

Waste conveyed from Single Shell tanks is generally destined for Double Shell tanks. The objective for SST retrieval is generally to remove waste to the greatest extent practical without regard to purity of the waste stream.

\subsubsection{Extent of Waste Transport from SST to DST to date?}


EM-21 - Input to "Retrieval of HLW Technical Requirements"

PWGibbons Inc

Historically waste slurry was pumped from tank to tank using legacy waste transfer lines, using the in-tank pump to both lift the waste and transfer it to the next tank. In many cases the liquid was decanted off and returned to the original tank via a sluicing jet to pick up more solids. This practice has generally ended and fresh water is generally used for slurry transport.

2.5.2.2.Primary requirements for Waste Transport from SST to DST

- Meet receiver requirements and required Transport velocities

- Prevent/mitigate plugging (velocity, temperature, solids loading, etc.)

- Buffer capacities (i.e., excess rate)

- Transport non-homogeneous waste

\subsubsection{Secondary requirements for Waste Transport from SST to DST}

- MONITORING/Process I\&C Minimize out-of-spec waste

- Sample and characterize (e.g., RDQO)

- Monitor progress

- Leak detection

- Quantify transfer volumes/mass

- Monitor receipt vessel

\subsubsection{TRANSPORT WASTE FROM DSTs TO WTP}

Waste removed from Double Shell Tanks for transport to the Waste Treatment Plant will be pumped directly from the DST to a WTP receiver tank. In this case attempts will be made to segregate the waste being transferred In order to meet the WTP waste feed specification.

2.5.3.1. What is the extent have we had to transport waste to date?

Waste transferred from DSTs to the Waste treatment plant will use the same method that is currently being used for inter-tank and evaporator transport. This uses mechanical pumps in conjunction with bulk slurry mixers to pump the waste slurry into a transfer line. In the case of transfer to WTP, a specific feed recipe specification will be targeted for each of four waste types. This will require some in-tank classification and blending or waste types.

\subsubsection{Primary requirements for Waste Transport from DST to WTP}

- Meet receiver requirements (e.g., ICD-19) and required Transport velocities

- Prevent/mitigate plugging (velocity, temperature, solids loading, etc.) Condition waste (Ensure batch homogeneity of feed to the facility

\subsubsection{Secondary requirements for Waste Transport from DST to WTP}


EM-21 - Input to "Retrieval of HLW Technical Requirements"

PWGibbons Inc

- MONITORING/Process I\&C Minimize out-of-spec waste

- Sample and characterize (e.g., RDQO)

- Monitor progress

- Leak detection

- Quantify transfer volumes/mass

- Monitor receipt vessel

3. CONCLUSIONS

4. APPENDICES

4.1.1. HANFORD STRATEGIC PLANNING WORKSHOP NOTES 
Appendix D

PNNL I SRNL FY09 RKC Plan - January 2009 

Office of Environmental Management Engineering and Technology Process and Systems Engineering

Retrieval Knowledge Center

FY2009 Strategy and Operating Plan

Pacific Northwest National Laboratory Savannah River National Laboratory NuVision Engineering

January 2009

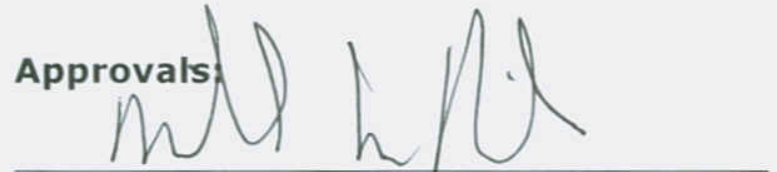

Michael Rinker

PNNL Project Lead

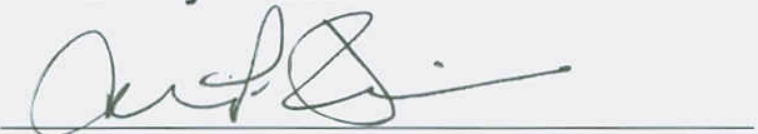

Andrew Fellinger

SRNL Project Lead

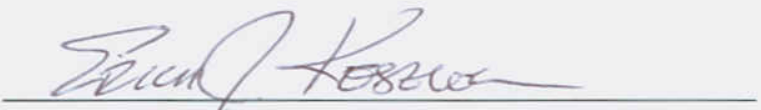

Erich Keszler

NuVisioh Engineering Project Lead

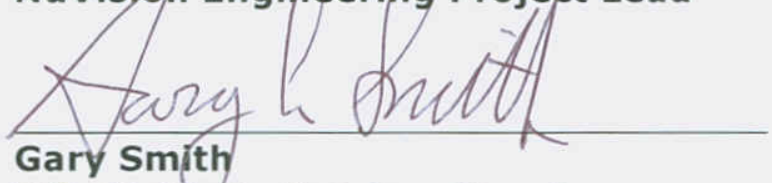

EM-21 Waste Retrieval Lead

Shanand) Mur

Sharon Marra

Initiative Development Team Lead

Waste Retrieval and Closure $\frac{1 / 30 / 09}{\text { Date }}$

$\frac{1 / 23 / 09}{\text { Date }}$

$\frac{1 / 13 / 2009}{\text { Date }}$

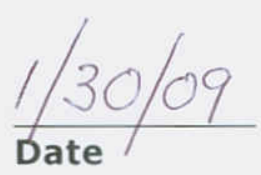

$\frac{1 / 2309}{\text { Date }}$ 
EM-21 Retrieval Knowledge Center

January 12, 2009

Revision 0

\section{Strategy and Operating Plan Summary for FY2009}

This strategy and operating plan describes the activities to be conducted by Pacific Northwest National Laboratory (PNNL) and the Savannah River National Laboratory (SRNL) in FY2009 and beyond in support of DOE's program to develop a Retrieval Knowledge Center (RKC). The activities will also include leveraged activities at NuVision Engineering that are funded under separate funding mechanisms. 
EM-21 Retrieval Knowledge Center January 12, 2009

Revision 0 

waste retrieval.

EM-21 Retrieval Knowledge Center January 12, 2009

Revision 0 
The Retrieval Knowledge Center will initially be an information library related to the remediation of radioactive wastes from underground storage tanks throughout the DOE complex especially the Hanford and Savannah River Sites. The information will be categorized into various functional attributes which will have the ability to be queried individually or as a group by searching or browsing. The goal is to provide users with easy access to this information. For documents, the goal is to provide both an electronic display of bibliographic information and download capabilities of complete documents for individual use.

The Retrieval Knowledge Center will leverage previous efforts that were started in 1996 by the DOE's Tanks Focus Area (TFA). This work was done by leveraging resources and working with a broad team of experts from industry, national laboratories, government contractors, universities, stakeholders, and the U.S. Department of Energy in a "community of practice" for tank waste retrieval. One of the goals of this effort is to supplement existing efforts to reinstate such a community. The Tanks Technology Guide was continuously updated and maintained through 2002. While the website is still accessible at www.tanks.org it does have some operational shortcomings. However, the database is still intact, and is located on a PNNL server.

Currently, the Retrieval Knowledge Center is focused only on waste retrieval activities; however, after the Retrieval Knowledge Center is operational and gains acceptance, it could be expanded to all of EM-21 to address other technical areas.

\section{Retrieval Knowledge Center Strategy}

The Retrieval Knowledge Center strategy is focused on three key activities. They are:

- the development of a centralized database on retrieval technologies

- documenting and making available the results from ongoing dialogs primarily with the Hanford and Savannah River Sites through a series of workshops and technical exchanges

- analysis of the available information in order to determine the technical gaps that, if filled appropriately, may provide system based solutions that will allow more effective retrieval.

Other sites, including Oak Ridge and Idaho, will be included as well in order to exchange technical information, issues, and lessons learned.

\section{Development of Retrieval Knowledge Center}

The Retrieval Knowledge Center information library will be hosted on the DOE EM-21 website. It will provide an updated information source for underground storage tank retrieval. The website itself will import existing databases including the Retrieval Technology Guide that was previously developed by the Tanks Focus Area. The goal is to import the existing database, and then populate with information that has been generated by the DOE HLW Tank Sites since 2002 when the TFA ceased operations. Assessment and attributions will be assigned to various documents in order to provide a level of importance of key information that exists in the database. The 
assessment will need to have careful consideration in order to ensure that separation of important data and features from less important data.

The development of the information library, database, and website will be completed by NuVision Engineering in cooperation with PNNL and SRNL. NuVision Engineering will work to obtain retrieval information from private enterprises as well as other government organizations (Navy, NASA, others) where systems that may be applicable to retrieval have been developed. SRNL and PNNL will coordinate additional tank retrieval information from the DOE Sites.

\section{Technical Dialog with High Level Waste Sites}

It is imperative to maintain a strong technical dialog and discussions with the High Level Waste Tanks Sites. Typically, technical dialog can be accommodated by various methods including e-mail, one-on-one discussions, telecons, limited attendance meetings, or facilitated workshops. While all of these methods are valuable, initial facilitated workshops which include diverse technical staff from the sites, national labs, industry leaders, DOE, and other stakeholders are needed in order to obtain enduring technical interactions that have been lacking for the past several years. Following an initial workshop, plans will be made for regular communications amongst the sites, developers, the DOE, and others. These communications need to be well documented in order to assess lessons learned, technical issues, and lay the groundwork for potential technical solutions.

In the near term dialog between and amongst the sites will be completed through workshops. Two workshops were recently held, one at Hanford (September 2008) and one at Savannah River (October 2008) where site and lab staff came together to discuss the functional aspects of retrieval, technical gaps as well as lessons learned in terms of things that worked. These initial workshops have set the stage for small focused workshops in order to understand the technical gaps and identify the next steps that would be necessary to address those gaps.

\section{I dentification of Technology Gaps}

While both Hanford and the Savannah River Sites have baseline technologies and approaches that will be utilized for High Level Waste tank retrieval efforts, there are gaps and unknowns that need to be identified in order to increase the probability that retrieval operations will be successful and effective. For example, a number of tanks at both sites have sludge in hard-to-reach locations, in-tank obstructions, and stubborn heels that may require other chemical or mechanical means to meet the retrieval requirements.

Technology gaps are not easy to identify and so a systematic approach will be necessary to identify them. Each retrieval step starting with deployment methods, how the waste will be mobilized or dislodged, the type of motive force used to "capture" and remove the waste from the tank, the transport of the waste in a transfer line all need to evaluated for a given retrieval technology in order to determine the gaps. Gap information will also be determined from a comprehensive review of the available reports and documents in the Retrieval Knowledge Center as well as multiple discussions with the end users. The technical gaps will need to be vetted and validated by the sites and DOE during the workshops and other 
interactions. Once validated, the technical gaps can be the basis of future focused technical retrieval needs.

\section{Retrieval Knowledge Center Workplan}

The Retrieval Knowledge Center was initiated by EM-21 in FY2008 to:

- I nitiate the generation of the waste retrieval database that will "go live" for use by others.

- Host workshops to identify and document high level requirements at both the Savannah River Site and the Hanford Site.

- Identify and document technical gaps for waste retrieval efforts at both the Hanford and Savannah River Sites.

\section{FY2008 Activities}

The activities associated with the Retrieval Knowledge Center for Fiscal Year 2008 funding included the development of this plan, working with NuVision Engineering for the initiation of the functional requirements and follow-on development of the website and database, and the initial documentation of system level retrieval requirements. In summary, the FY2008 activities were:

- Develop the Retrieval Knowledge Center Strategic Plan.

- Documentation of high level retrieval requirements through workshops at Hanford and Savannah River.

- Initiation of the Retrieval Knowledge Center Website and Database.

- Initiate retrieval workshop planning activities.

\section{FY2009 Activities}

The FY2009 work plan for the Retrieval Knowledge Center will be executed by three primary organizations. The Pacific Northwest National Laboratory will lead the Retrieval Knowledge Center activities; however, PNNL will work in close collaboration and partnership with the Savannah River National Laboratory. SRNL and PNNL will work together to coordinate and host workshops, interface with the Hanford and Savannah River Site tank farm organizations, and to develop viable technical plans to address the technical gaps.

Under separate funding, NuVision Engineering's primary role on this work will be to help develop and disseminate the technical information that is available on retrieval technologies from private sector work, other DOE retrieval work, and from other government agency work that may be applicable to Hanford and Savannah River tank waste retrieval operations. NuVision Engineering will also manage development of the website database information library and integrate into the DOE EM-21 website, if possible. 
FY2009 activities for the Retrieval Knowledge Center are based upon the successful outcome of the initial workshops held at the Hanford and Savannah River Sites in September and October 2008, respectively, to identify the high level retrieval requirements and gaps that need to be addressed in order for retrieval to become more successful. One additional technical focused workshop session is planned and will be held on specific areas and requirements determined by the priorities established in the retrieval requirements documentation. The result of these focus sessions will result in substantive plans that, if implemented, will provide necessary improvements for successful tank waste retrieval.

In summary the FY2009 activities are:

- Initiate systems analysis of technical gaps within waste retrieval and identify solutions or technology deployment programs.

- Completion and "Go-Live" of the Retrieval Knowledge Center including integration of the existing database.

\section{Task 1 Technical Gap Solutions and Documentation}

The objective of this task is to develop technical solutions to gaps identified at the retrieval workshops held at Hanford and Savannah River during the Fall of 2008. This will be accomplished through several focused workshops that will occur and will be documented during the second or third quarter of FY2009.

Four technical focus sessions will be held in FY2009 based upon consideration of the documentation from the first Retrieval Knowledge Center workshops held at Hanford and Savannah River. These workshops will include key staff from both sites as well as key staff from the labs and from NuVision Engineering. The purpose of the workshops will be to:

- Review and validate the technical gaps that were been identified during the retrieval workshops at Hanford and Savannah River held in the Fall of 2008.

- Determine the detailed technical requirements necessary to address the gaps.

- Review technical retrieval information from industry, the DOE Sites, and other organizations that may be applicable to address the technical gaps.

- Identify and document a technical strategy that, if implemented, would effectively address the technical gaps.

SRNL will be responsible for the coordination of SRS staff participation from both the Liquid Waste Operations as well as SRNL technologists. PNNL be responsible for the coordination of Hanford staff participation from both the Tank Farm Operations as well as PNNL technologists. NuVision Engineering will be responsible for providing technical information and details of industry and other government organization retrieval technologies that may be applicable. PNNL and SRNL will coordinate with Oak Ridge and Idaho staff for participation as appropriate with regard to the technical content of each workshop. 


\section{Task 2 Retrieval Knowledge Center Database}

The objective of this task is to complete the creation of the Retrieval Knowledge Center database, release it for use across the DOE Complex, and to ensure that it is populated with technical retrieval information that is available within the DOE Complex with private industry and other organizations.

The proposed work for FY2009 includes the completion of the website and database for the Retrieval Knowledge Center, the incorporation of the existing Retrieval Technology Guide that has not been maintained since 2002 and incorporation of retrieval documents that have been generated since 2002. Primarily this will be completed by NuVision Engineering. NuVision Engineering will complete the website development, ensure that it meets DOE EM website guidelines, and incorporate documentation from the previous Tanks Technology Guide.

NuVision Engineering, SRNL and PNNL will all work together to ensure that DOE retrieval documents that have been generated since 2002 are incorporated into the website.

Also, NuVision Engineering will specifically review available technical information from private industry and other government organizations where technologies applicable to retrieval have been developed. PNNL, SRNL, and NuVision Engineering will review and enter that information into the website, and lead a review of the pertinent technical information at the workshops.

\section{FY2010 - Proposed Activities}

The proposed work for FY2010 is to maintain and update the Retrieval Knowledge Center, and to work with the other technical areas of the EM-21 program to expand the Retrieval Knowledge Center across the EM-21 program. Additional workshops will be held, and technical gaps will be documented and validated. Proposed solutions to the gaps will be generated for inclusion into the EM-21 needs assessment and prioritization.

\section{Primary Participants Roles and Responsibilities}

Three organizations will be the primary participants for the development of the Retrieval Knowledge Center.

PNNL - The Pacific Northwest National Laboratory (PNNL) is the lead for the RKC and will also be responsible for developing the retrieval requirements, will lead the efforts for the retrieval gap analysis, and be responsible for completing and issuing the documentation. PNNL will work closely with the Hanford retrieval end users.

SRNL - Savannah River National Laboratory (SRNL) will also provide leadership and regular interaction and direction over the NuVision's development of the Retrieval Knowledge Center website. SRNL will work closely with the Savannah River Site retrieval end users.

SRNL and PNNL will work together to plan, host, and document the Retrieval Knowledge Center workshops. 
Nu-Vision Engineering - NuVision Engineering will be responsible for the overall RKC website development. They will develop and document the website that will become part of the EM-21 DOE website. NuVision will be responsible for maintaining the RKC website. In addition, they will review commercial technologies that are available for potential deployment. Furthermore, NuVision Engineering will provide technical context and dissemination of information regarding private industry and other government organization technologies that may be applicable to retrieval. NuVision will also participate in the workshops and provide technical context regarding potential applicable technologies. NuVision Engineering is funded through the DOE International Grant program.

The primary roles and responsibilities for each participant are shown in Appendix A.

\section{FY2009 Spend Plan}

The spend plan and budget for this effort is contained in other documentation by EM21. However, FY2009 funding tasks will be initiated in December 2008 upon receipt of funds at PNNL and SRNL. The current planning assumes two workshops, which are planned in March and May of 2009. This does not include NuVision Engineering costs. Carryover from FY2008 was utilized during the $1^{\text {st }}$ quarter of FY2009. We are currently operating under continuing resolution, thus, funded incrementally each month. We expect to receive full project funding by March 2009.

\section{Milestone and Delivery Summary}

\begin{tabular}{|l|c|}
\hline \multicolumn{1}{|c|}{ Milestone } & Date \\
\hline Issue Technical Focus areas for FY2009 Workshops (PNNL/SRNL) & February 2009 \\
\hline Initial rollout of website (NuVision Engineering) & February 2009 \\
\hline $\begin{array}{l}\text { Provide technical document input to RKC website and NuVision } \\
\text { Engineering (PNNL) }\end{array}$ & March 2009 \\
\hline $\begin{array}{l}\text { Document Workshop results and issue to RKC website (PNNL/SRNL) } \\
\text { J une 2009 }\end{array}$ \\
\hline
\end{tabular}




\section{Appendix A - Roles and Responsibility Matrix}

\begin{tabular}{|c|c|c|c|c|c|}
\hline & Task & $\begin{array}{c}\text { Primary } \\
\text { Responsibility }\end{array}$ & $\begin{array}{c}\text { Support } \\
\text { Responsibility }\end{array}$ & Mechanism & Ref \\
\hline 1 & $\begin{array}{l}\text { Develop retrieval } \\
\text { requirements }\end{array}$ & PNNL & SRNL & Workshops & $\operatorname{Pg} 7,8,9$ \\
\hline 2 & $\begin{array}{c}\text { Manage development } \\
\text { of website database } \\
\text { and information } \\
\text { library }\end{array}$ & NVE & & $\begin{array}{c}\text { PTP / } \\
\text { Subcontract }\end{array}$ & Pg 6, 9 \\
\hline 3 & $\begin{array}{l}\text { Maintenance of } \\
\text { website }\end{array}$ & NVE & & $\begin{array}{l}\text { FY09 / FY10 } \\
\text { 1A Funding }\end{array}$ & Pg 9 \\
\hline 4 & $\begin{array}{l}\text { Review of commercial, } \\
\text { private sector, gov } \\
\text { (non-DOE) } \\
\text { technologies } \\
\text { applicable to tank } \\
\text { waste retrieval }\end{array}$ & NVE & PNNL/SRNL & $\begin{array}{l}\text { Web searches } \\
\text { / customer } \\
\text { visits }\end{array}$ & $\begin{array}{l}\mathrm{Pg} 4,6 \\
9,10\end{array}$ \\
\hline \multirow{2}{*}{5} & \multirow{2}{*}{$\begin{array}{c}\text { Dissemination of } \\
\text { commercial, private } \\
\text { sector, gov (non-DOE) } \\
\text { technologies } \\
\text { applicable to tank } \\
\text { waste retrieval }\end{array}$} & NVE & & $\begin{array}{l}\text { Port TFA / } \\
\text { tanks. org info } \\
\text { into website }\end{array}$ & \multirow{2}{*}{$\operatorname{Pg} 7,10$} \\
\hline & & & PNNL & $\begin{array}{l}\text { Supply NVE } \\
\text { with TFA / } \\
\text { tanks.org info }\end{array}$ & \\
\hline \multirow[t]{2}{*}{6} & \multirow{2}{*}{$\begin{array}{c}\text { Dissemination of } \\
\text { commercial, private } \\
\text { sector, gov (non-DOE) } \\
\text { technologies } \\
\text { applicable to tank } \\
\text { waste retrieval }\end{array}$} & NVE & & $\begin{array}{l}\text { Web searches } \\
\text { / discussions } \\
\text { with site } \\
\text { personnel }\end{array}$ & \multirow[t]{2}{*}{ Pg 5, 8} \\
\hline & & & PNNL & $\begin{array}{l}\text { Supply NVE } \\
\text { with TFA / } \\
\text { tanks.org info }\end{array}$ & \\
\hline \multirow{2}{*}{7} & \multirow{2}{*}{$\begin{array}{l}\text { Documentation of } \\
\text { waste retrieval } \\
\text { activities since } 2002 \\
\text { (post-TFA) }\end{array}$} & NVE & & $\begin{array}{l}\text { Web searches } \\
\text { / discussions } \\
\text { with site } \\
\text { personnel }\end{array}$ & \multirow{2}{*}{ Pg 9} \\
\hline & & & PNNL/SRNL & $\begin{array}{l}\text { Workshops / } \\
\text { discussions } \\
\text { with site } \\
\text { personnel } \\
\end{array}$ & \\
\hline \multirow[b]{2}{*}{8} & \multirow{2}{*}{$\begin{array}{c}\text { Determination of } \\
\text { performance data to } \\
\text { "quantify" success of } \\
\text { technology }\end{array}$} & PNNL/SRNL & & TBD & \multirow[b]{2}{*}{--} \\
\hline & & & NVE & TBD & \\
\hline \multirow[t]{2}{*}{9} & \multirow{2}{*}{$\begin{array}{l}\text { Technical dialogue } \\
\text { with end users }\end{array}$} & PNNL/SRNL & & $\begin{array}{l}\text { Workshops, } \\
\text { site visits }\end{array}$ & \multirow[t]{2}{*}{ Pg 6} \\
\hline & & & NVE & Site visits & \\
\hline \multirow[b]{2}{*}{10} & \multirow[b]{2}{*}{$\begin{array}{l}\text { I dentification of } \\
\text { technical gaps }\end{array}$} & PNNL & & Workshops & \multirow[b]{2}{*}{$\operatorname{Pg} 7,9$} \\
\hline & & & NVE & $\begin{array}{c}\text { Prioritization } \\
\text { knowledge } \\
\text { transfer }\end{array}$ & \\
\hline
\end{tabular}





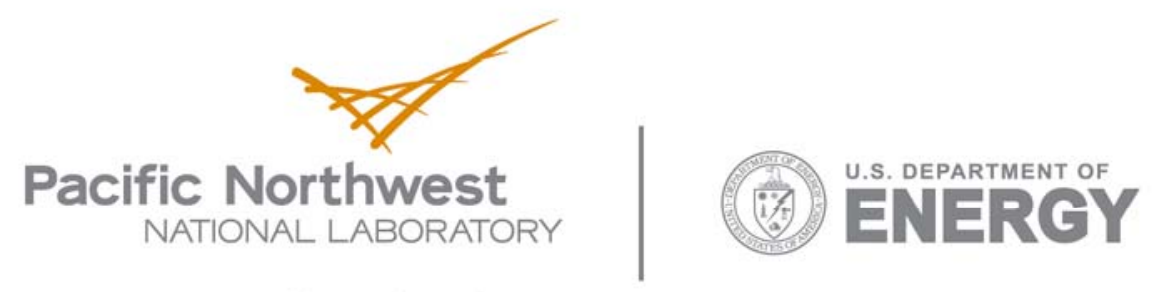

902 Battelle Boulevard

P.O. Box 999

Richland, WA 99352

1-888-375-PNNL (7665)

www.pnl.gov 